- Yu, P. and Luu, B.V. (2015) Bank performance and Executive Pay: Tournament or Teamwork, Review of Quantitative Finance and Accounting, accepted on the $17^{\text {th }}$ of April, 2015.

- This is our final author manuscript for Review of Quantitative Finance and Accounting.

$\circ$ Review of Quantitative Finance and Accounting has a 12mth embargo from first publication

\title{
Bank Performance and Executive Pay: Tournament or Teamwork
}

\author{
Peiyi Yu ${ }^{1}$ and Bac Van Luu ${ }^{2}$
}

${ }^{1}$ Peiyi (Ellen) Yu is the corresponding author.

Affiliation: University of East London, University Way, London E16 2RD, UK.

Email address: peiyi_yu@ymail.com

${ }^{2}$ Bac Van Luu

Affiliation: Norges Bank Investment Management. Queensberry House, $5^{\text {th }}$ Floor, 3 Old Burlington Street, London, W1S 3AE, UK 
Bank Performance and Executive Pay: Tournament or Teamwork 
We investigate the relationship between the dispersion of executive pay and bank performance/valuation by examining two competing theories, the tournament theory (hierarchical wage structure) and the equity fairness theory (compressed wage structure). The key variable of executive pay dispersion is measured using a hand-collected dataset composed of 63 banks from OECD countries and 29 banks from developing countries. The dataset covers the period 2004 to 2012. By combining and modifying a translog profit function and a pay-dispersion model, we are able to address the potential problems of relying on reducedform estimation. In our subsample of developed and civil law countries, where bank performance is measured by either Tobin's Q or by the price-to-book ratio, the overall impact of executive pay dispersion is mostly negative, and we find supporting evidence for the equity fairness theory, except for very high levels of dispersion. There is a non-linear effect, as banks perform best when there is either very low or very high executive pay dispersion. For developing country sample banks, greater executive pay dispersion has a negative impact on bank profit. In our subsample of common law countries, however, we find no evidence of a significant impact of executive pay dispersion on bank performance. We conclude that lower executive pay dispersion, a proxy for teamwork, is mostly effective in enhancing bank performance in a significant section of sample banks, i.e., civil law and developing countries.

Keywords: equity fairness theory; tournament theory; pay dispersion; executive compensation; banking; translog profit function

JEL codes: G20, G21, G28, G34, J33, M52 


\section{Introduction}

Executive compensation in banks has been severely criticized in the aftermath of the bail-out of the financial services industry during the global financial crisis. Marshall (2009) notes that performance-related executive pay may have incentivized excessive risk-taking and short-term thinking. In this paper, we investigate the relationship between the dispersion of executive pay and bank performance by examining two theories, the tournament theory (a hierarchical wage structure) and the equity fairness theory (compressed wage structure). The need for such research has gained in importance and urgency recently as compensation issues have figured quite prominently in broader discussions concerning the relationship between effective corporate governance and bank performance. Moreover, policymakers care about the design of executive pay at banks because the systemic importance of banks and the use of taxpayer money to rescue failing institutions distinguish them from non-financial corporations.

There has been a long-standing debate in the executive compensation literature as to whether higher or lower pay dispersion can enhance organizational performance. In sports, previous studies have gathered supporting evidence for the tournament theory and suggest that golfers' performance improves as prize differentials increase. For professional racing drivers, pay dispersion also has a positive impact on both individual performance and driver safety. Mikovich and Newman (1999) compare a corporate setting where individual performance matters most with a golf tournament. Greater pay dispersion is believed to improve organizational outcomes in such situations. However, the issue of pay dispersion has not received much attention in the banking literature. Conversely, a baseball game relies on individual effort as well as cooperation among team members and is said to benefit from greater equity in pay. In this study, we examine whether the banking industry is more like a round of golf or a baseball game in terms of the impact of executive pay dispersion. In particular, we look at pay dispersion at the top executive level and test whether the tournament theory (favoring greater pay dispersion) or the equity fairness theory (arguing for smaller pay dispersion) is applicable to bank performance.

This debate has been relatively little informed by detailed empirical research on financial firms, and comparative studies across countries are also relatively rare. Most of the previous studies exclude financial service companies because financial institutions have different characteristics from other industries. In addition, scholars commonly used reduced-form models by including two or three more factors as control variables in their main equations for controlling the firm differences in the human capital of the workforce, the industry, and the firm size. Because the control variables used in these reduced-form models can be somewhat arbitrary, our paper addresses the potential problems of relying on reduced-form estimation. 
We develop an operational measure of how hierarchical or compressed the wage structure is within the top executive level and examine its relationship with bank performance. Our dataset ranges from 2004 to 2012 and includes 92 sample banks across 18 developed countries in the OECD and two developing countries, China and India. We control for the impact from different bank regulatory systems, capital adequacy, and corporate governance variables, while we investigate the relationship between pay dispersion and bank profit. To overcome the limitations of relying on a reduced-form model, our proposed model is based on the combination of a pay-dispersion model and a modified translog profit function applied to the banking industry. Thus, our model offers a more solid theoretical background than the reduced-form model.

Furthermore, we study whether differences among countries that are proxied by the level of capital market development and legal system influence the relationship of pay disparity and bank performance. For that purpose, we classify our sample banks into the following five groups: (a) global (comprising all banks), (b) developing country banks (c), developed country banks (d), civil law country banks, and (e) common law country banks. The remainder of this paper is organized as follows. Section 2 discusses prior related research. Section 3 describes our theoretical model, while Section 4 presents our empirical results and reports on our various robustness tests. Section 5 concludes the study.

\section{Literature Review}

Prior research on compensation and performance first investigated chief executive pay, then expanded the scope to the compensation of the entire managerial team. For example, Aggarwal and Samwick (2003) suggest that pay-performance sensitivity increases with the span of authority. Barron and Waddell (2003) find that higher-ranking managers have a greater proportion of incentive-based compensation in pay packages than do lower-ranked executives. Overall, the early literature on executive compensation primarily focuses on issues related to the level and structural mix of compensation packages and their sensitivity to firm performance (e.g., Kale et al. 2009; Cheung and Corrado 2008; Blackwell et al. 2007; Bryan et al. 2000; Aggarwal and Samwick 1999; Murphy 1999; Hall and Liebman 1998; Lambert and Larcker, 1987). However, studies on the impact of executive compensation in the financial and banking sector are scarce. One exception is Becht et al. (2011), who suggest that more shareholder power can lead to more risk taking; therefore, equity-based incentives for executives can lead to more risk taking. In this study, we examine tournament and equity fairness as two competing theories of executive compensation for a global sample of banks. 
Tournament theory (Grund and Westergaard-Nielsen 2008; and Kaleet al. 2009) predicts that compensation across managers will be more dispersed than under the equity fairness theory. The tournament theory is also known as the hierarchical pay hypothesis in the literature. It was first developed by Lazear and Rosen (1981), who contend that compensation spreads are not based on marginal productivity but on relative differences between individuals. In the presence of a tight positive relationship between employee effort and output, efficiency can be secured by the widening of pay dispersion across the corporate hierarchy toward top positions. Good examples of the applicability of the tournament theory can be found in professional sports.

The theory of equity fairness (Wade et al. 2006) indicates that large pay dispersion can increase envy and dysfunctional behavior among team members. This may give rise to negative effects of pay disparity on firm performance. The equity fairness theory is similar to the wage compression hypothesis. According to Lazear (1989), wage dispersion affects not only the final team output but also the way this output is produced. Members of high-inequality teams behave less cooperatively and act more selfishly than members of teams with a compressed wage structure. Although the issue of pay dispersion across managerial team members has received conceptual attention, the empirical results generated from previous studies vary considerably.

\subsection{Tests of the tournament theory}

The important principle of the design of corporate tournaments is that greater pay dispersion can motivate managers to expend greater efforts that increase their firm's performance. In other words, the compensation spread across manager levels could provide extra incentives to participate in the managerial tournament and to make considerable efforts to win the top executive job. Ehrenberg and Bognanno (1990) obtain supporting evidence for the tournament theory in sport settings and indicate that golfers' performance improves as prize differentials increase. In a similar vein, Becker and Huselid (1992) investigate the performance of professional racing drivers and find that pay dispersion has a positive impact on both individual performance and driver safety.

The empirical evidence on the tournament theory obtained from the business settings side is rather limited and somewhat mixed. Main, O'Reilly and Wade (1993) use survey data for 200 firms from 1980 to 1984 and report that firm performance is positively related to executive pay dispersion. Conyon and Murphy (2000) examine a sample of 100 large UK firms from 1997 to 1998 and find no evidence that large pay dispersion is positively associated with improved firm performance. O’Reilly, Main and Crystal (1988) also 
report similar findings for the United States. However, Lee et al. (2008) examine 1855 listed US companies (utility and financial services companies were excluded) for the period 1992-2003 and find that firm performance, measured either by Tobin's Q or by the firm's stock return, is positively related with the pay disparity among top management.

In a similar vein, Heyman (2005) detects evidence in favor of the tournament theory by employing a large matched employer-employee data set for Sweden. By using data for approximately 10,000 managers, his empirical results indicate that there is a positive and significant association between managerial pay dispersion and profits. The work of Chen et al. (2011) also suggests that the tournament theory describes the pay-performance relationship well in a sample of 432 listed companies in China from 1998 to 2009. Moreover, they indicate that the relationship between executive pay dispersion and firm performance is weakened by higher government ownership. In that case, the level of executive remuneration is positively related to the level of executives' political power rather than firm performance. However, financial services companies were excluded in the study.

\subsection{Tests of the equity fairness theory}

Akerlof and Yellen (1988, 1990), Milgrom and Roberts (1988 and 1992), and Levine (1991) argue that low pay dispersion may have a positive effect on employee efforts and productivity by creating harmonious and efficient labor relations, thereby increasing output and productivity. Levine (1991) develops a model showing that lowering pay dispersion can increase employee cohesiveness, which in turn will increase productivity. Lazear (1989) and Milgrom and Roberts (1990) provide further insight into the economic efficiency associated with low pay dispersion. These studies indicate that if promotion and salaries are based on relative rather than individual performance, as proposed by tournament theory, then employees will advance not only by performing well but also by seeing to it that their rivals perform poorly. Consequently, high pay dispersion may weaken employees' incentives to cooperate. In other words, a firm can encourage cooperation by reducing pay dispersion. Lazear (1989) indicates that low dispersion may reduce efforts but simultaneously increase cooperation. Thus, it may be optimal on productivity grounds to compress the wage structure to promote cooperation.

Empirical tests of the equity fairness theory are somewhat supportive. Cowherd and Levine (1992) report that there is a positive relationship associated with product quality and low wage dispersion between lowlevel employees and management. Studying university faculties, Pfeffer and Leangton (1993) suggest that 
higher wage dispersion leads to lower satisfaction and research productivity among faculty members and a decreased likelihood that they would collaborate on research. Using Australian data, Drago and Garvey (1998) find that strong promotion incentives reduce employee cooperation and individual efforts. Contradicting the equity fairness theory, Hibbs and Locking (2000) report that compression of wage dispersion in Swedish companies depresses output and labor productivity.

\subsection{Comparative evidence}

Comparative studies are relatively rarer. Beaumont and Harris (2003) investigate whether a hierarchical or compressed wage structure has a positive impact on organizational performance by employing UK manufacturing micro-data in five industrial sectors. They define wage compression (pay dispersion within the whole firm, not just the executive level) as the ratio of non-manual to manual labor costs per employee. They find supporting evidence for the wage compression theory in one sector, but not the other four sectors. Moreover, their results indicate that two intra-industry characteristics, namely, size and ownership differences, weaken the relationship.

\section{Model}

Because theory does not provide strong arguments in favor of one or the other theory, the nature of the relationship between executive pay dispersion and bank performance remains an empirical question. This study fills the empirical gap by investigating the relationship between pay dispersion at the top executive level and bank performance. Our theoretical model is inspired by the following two studies: (1) a translog profit function introduced by Mullineaux (1978), which is used to estimate economies of scale and efficiency, and (2) a pay-dispersion model proposed by Franck and Nüesch (2011), which focuses on the impact of intra-team pay dispersion on German soccer team productivity. By modifying these two models, we are able to address the potential problems of relying on reduced-form estimation.

\subsection{Modeling bank performance}

In previous studies of the pay dispersion-performance relationship, scholars commonly use reduced-form models, although the control variables used in these reduced-form models can be somewhat arbitrary. In our opinion, the unique nature of the banking industry, i.e., the combination of labor, interest, and capital to produce banking services, is captured more fully by incorporating the characteristics of the translog profit 
function rather than a reduced form model. Therefore, most of the bank-specific independent variables we adopt in this study are based on the conventional translog profit function.

The theory of the profit function for competitive firms and the relationship of the profit function with the Cobb-Douglas production were originally developed by McFadden (1966). Then, Lau (1969) extended the theory to noncompetitive situations. One of the most widely used flexible functional forms for a profit function is the transcendental logarithmic function form because this form is easily adaptable to include multiple banking outputs and inputs (Diewert 1973; Yotopoulos and Lau 1973; Mullineaux 1978; Hancock 1992; Akhavein et al.1997). These previous studies, which mainly focus on economies of scale and efficiency, present a straightforward application of the translog profit function to the commercial banking industry. Overall, the profit function has the following two desirable features: (a) Based on certain assumptions, a one-to-one correspondence exists between the set of concave production functions and the set of convex profit functions. (b) The level of output is not a variable in the profit function. This design is superior to the bank cost functions, which have had difficulties in defining the output of commercial banks.

A typical full translog profit function (Diewert 1973; Mullineaux 1978) includes the following three key factors: (1) outputs (2) inputs and (3) fixed factors. These three types of key factors must be measured as "prices of output variables", "prices of input variables" and "quantities of the fixed factors", as in equation (1). To model bank performance as a function of the prices of bank outputs, the prices of inputs, and the quantities of fixed factors is a significant and justifiable departure from the common practice of regressing bank performance against somewhat arbitrary lists of explanatory variables, including executive pay variables. The translog profit function is based on microeconomic theory; hence, we consider it a structural framework. The translog profit function theory provides a solid background to explain why output prices, prices of variable inputs, and quantities of fixed factors can serve as control variables for our model of executive pay dispersion and bank performance.

$$
\begin{aligned}
& \text { ln profit }=a_{0}+\sum_{i=1}^{m} a_{i} \ln \left(\text { output }_{i}\right)+\sum_{j=1}^{n} b_{j} \ln \left(\text { input }_{j}\right)+\sum_{k=1}^{p} c_{k} \ln \left(\text { fixedfactor }_{k}\right) \\
& +\frac{1}{2}\left[\sum_{i=1}^{m} \sum_{k=1}^{m} \mathrm{~g}_{j k} \ln \left(\text { output }_{i}\right) \ln \left(\text { output }_{k}\right)+\sum_{j=1}^{n} \sum_{k=1}^{n} h_{j k} \ln \left(\text { input }_{j}\right) \ln \left(\text { input }_{k}\right)\right. \\
& \left.+\sum_{k=1}^{j=p} \sum_{j=1}^{p} l_{k j} \ln \left(\text { fixedfactor }_{k}\right) \ln \left(\text { fixedfactor }_{j}\right)\right]+\sum_{i=1}^{m} \sum_{j=1}^{n} q_{i j} \ln \left(\text { output }_{i}\right) \ln \left(\text { input }_{j}\right) \\
& +\sum_{i=1}^{m} \sum_{k=1}^{p} r_{j k} \ln \left(\text { output }_{i}\right) \ln \left(\text { fixedfactor }_{k}\right)+\sum_{j=1}^{n} \sum_{k=1}^{p} s_{j k} \ln \left(\text { input }_{j}\right) \ln \left(\text { fixedfactor }_{k}\right),
\end{aligned}
$$

where: 
"profit" is defined as total revenue minus the cost of the variable factors of production,

"output" is the $m$ bank output prices,

"input" is the prices of the $n$ variable inputs,

and "fixedfactor" is the quantities of the fixed factors of production.

Overall, the use of the translog profit function can capture the special features of financial institutions that have previously been excluded from most studies of pay dispersion and firm performance.

\subsection{Modeling pay dispersion}

Most empirical studies investigating the effect of pay dispersion on firm performance can be divided into linear and non-linear models. The existing literature largely concentrates on linear effects (Cowherd and Levine 1992; Heyman 2005; Hibbs and Locking 2000; Pfeffer and Leangton 1993), while Grund and Westergaard- Nielsen (2008) and Franck and Nüesch (2011) propose that the relationship between intrateam wage differentials and team performance is less likely to be linear under the two competing paradigms discussed earlier, namely, the tournament and equity fairness theories.

Tournament theory asserts that the intra-team wage structure can be viewed as an incentive design that attracts talent and stimulates individual effort. The theory can be articulated by assuming that the banking firm's total performance $T P_{t}$ is a positive function of pay dispersion $x$, here measured at the top executive level of banks:

$$
T P_{T}=\alpha+\alpha x^{r}
$$

By assuming $\alpha>0$ and $r>0$, a positive impact of wage inequality on productivity through the magnitude and the slope is posited.

However, under the equity fairness theory, team performance reacts negatively to the increase in wage dispersion. This negative relationship can be shown as

$$
T P_{E F}=-b x^{t},
$$

where $b>0$ and $t>0$. 
The overall effect of executive pay dispersion on banking firm performance would be the sum of these two equations, where $a x^{r}$ represents the positive impact proposed by the tournament theory and $-b x^{t}$ represents the negative impact proposed by the equity fairness theory (Grund and Westergaard- Nielsen 2005; Franck and Nüesch 2011):

$$
T P(x)=\alpha+T P_{T}(x)-T P_{E F}(x)=\alpha+\alpha x^{r}-b x^{t}
$$

Based on equation (4), the values of $a, b, r$ and $t$ will determine the shape of the function of company performance. A linear relationship only exists if $r=t=1$. If $r>t$, the function of company performance will be U-shaped with a local minimum at $(t b / r a)^{1 /(r-t)}$, while with $r<t$, an inverse U-shape will be formed. If non-linearities as modeled here are present in the relationship between pay dispersion and performance, it may explain why the results of the previous empirical studies using linear effects vary considerably.

These three equations summarize most of the previous empirical findings examining linear effects $(r=t=1)$ and non-linearity (when $r \neq t$ ) in the relationship between pay dispersion and firm performances. To allow for potential non-linearity in our study, we include a linear term of paydisp and the quadratic term paydisp ${ }^{2}$ in our theoretical model.

Some previous studies, for example, Lee et al. (2008), Barron and Waddell (2003), and Hibbs and Locking (2000), employ the coefficient of variation (CV) as their indicator of pay dispersion, while other definitions of pay dispersion can also be found in the literature. Heyman (2005) define pay dispersion as the 90-10th percentile wage ratio. Chen et al. (2011) collect actual pay for each of the three highest paid executives for all disclosing Chinese listed companies between 1999 and 2009 and then measure wage dispersion as follows: $W D=\log \left(w_{1}\right)-\log \left(w_{A}\right)$, where $w_{1}$ is the remuneration of the highest paid executive, and $w_{A}$ is the average remuneration of the second- and third-highest paid executives. The Gini coefficient has also been used as a measure of pay dispersion (Lehmann and Schulze 2008). Since Franck and Nüesch (2011) indicate that the Gini coefficient and the coefficient of variation (CV) are strongly correlated, we adopt the coefficient of variation $(\mathrm{CV})$ of total compensation as our only indicator of the variable of pay dispersion in this study. The coefficient of variation $(\mathrm{CV})$ is a normalized measure of dispersion of a probability distribution and is computed as the ratio of the standard deviation to the mean. 
We will provide a detailed explanation how we build a hand-collected database of top five executive pay (actual compensation) for our sample banks from 2004-2012 for our 92 sample banks worldwide. We will provide a discussion on our collection process in section 4.1 .

\subsection{Combined model and variable definitions}

In standard production theory, profits come from the flow of output during the production period. However, banks earn profits on various outputs such as different types of loans and bank services. In the banking literature, the three key input variables commonly adopted in a conventional profit translog function are interest costs, labor costs, and capital costs (Mullineaux 1978; Hancock 1992; Akhaveinet al. 1997). In the modern banking industry, these three factors remain the key input variables for banking firms in order to produce either traditional banking outputs or innovative banking services. The quantity of fixed inputs cannot be changed during the production period. For example, the average size of the bank firm and the regulatory environment can be viewed as fixed factor variables.

Our main model is in equation (5), which is based on the combination of a pay dispersion model and a modified translog profit function applied to the banking industry. Based on our previous discussion of modeling pay dispersion, we include a linear term and the quadratic term of pay dispersion in the model. In addition to our original performance indicator, the variable "Profit", we investigate two further performance measures that relate to the market's valuation of banks, namely, Tobin's $\mathrm{Q}$ and the price-to-book $(\mathrm{P} / \mathrm{B})$ ratio. If compensation includes stock options, executives may target market valuations and share prices rather than operational performance measures such as profit. In this model in equation (5), we also control for the impact from different bank regulatory systems, capital adequacy, and corporate governance variables, while we investigate the relationship between the variable of pay dispersion at the top executive level and these indicators of bank performances. Overall, there are four categories of variables in our major equation: (a) banking firms' performance indicators, (b) banking firms' inputs, (c) banking firms' outputs, and (d) control variables with regard to the different regulatory systems, capital adequacy, and corporate governance.

performance $_{i t}=a_{0}+r\left(\right.$ paydisp $\left._{i t}\right)+s\left(\text { paydisp }_{i t}\right)^{2}+a \ln \left(\right.$ output $\left._{i t}\right)+\sum_{j=1}^{n} b_{j} \ln \left(\right.$ input $\left._{j i t}\right)+c \ln \left(\right.$ fixedfactor $\left._{i t}\right)$

$+\frac{1}{2}\left[\mathrm{~g} \ln \left(\right.\right.$ output $\left._{i t}\right) \ln \left(\right.$ output $\left._{i t}\right)+\sum_{j=1}^{n} \sum_{k=1}^{n} h_{j k} \ln \left(\right.$ input $\left._{j i t}\right) \ln \left(\right.$ input $\left._{\text {kit }}\right)+l \ln \left(\right.$ fixedfactor $\left._{i t}\right) \ln \left(\right.$ fixedfactor $\left.\left._{i t}\right)\right]$

$+\sum_{j=1}^{n} q_{j} \ln \left(\right.$ output $\left._{i t}\right) \ln \left(\right.$ input $\left._{j i t}\right)+r \ln \left(\right.$ output $\left._{i t}\right) \ln \left(\right.$ fixedfactor $\left._{i t}\right)+\sum_{j=1}^{n} s_{j} \ln \left(\right.$ input $\left._{j i t}\right) \ln \left(\right.$ fixedfactor $\left._{i t}\right)$

$+\sum_{j=1}^{n} m_{j}\left(\operatorname{control}_{j i t}\right)$ 
where the control variables control $_{j}$ are the dummy variables for widely owned and CEO duality, the variable of capital adequacy, the variable of default risk, and the dummy for development status.

\section{Bank Performance Indicators}

Undoubtedly, bank profit should be chosen as one of our performance indicators. However, more than one proxy for bank performance was adopted because we also examine whether pay dispersion is reflected in how the stock market values banks. For example, the European Central Bank (2010) notes that among the large set of performance measures for banks used by academic and practitioners alike, a distinction can be made among traditional, economic, and market-based measures of performance. Thus, our study adopts three indicators of bank performance as follows: profit, Tobin's $\mathrm{Q}$, and the $\mathrm{P} / \mathrm{B}$ ratio. The profit indicator is employed as the measure representing operational performance, while Tobin's Q and the P/B ratio (Lee et al. 2009; Claessens 2006; Caprio et al.2004) are adopted as the indicators representing the market valuation of our sample banks. Some prior studies (Lee et al. 2007; Himmelberg et al. 1999) also measure firm performance by Tobin's $\mathrm{Q}$ and regress it by executive pay dispersion and a set of control variables.

\section{Banking Firms' Inputs}

To estimate the prices of banking firms' inputs, we include interest price and labor price as the two input variables, which are also commonly viewed as key inputs in the banking literature on the translog profit function and translog cost function (Yu and Luu 2003).

\section{Banking Firms' Outputs}

We consider that the modern banking industry has more diversified businesses rather than simply operating in the traditional banking loan business. In contrast to previous studies in banking (Berger and Deyoung 1997), which mainly use loan rates, the variable of our output is defined by us as the total income divided by total earning assets. More precisely, all of the incomes generated by banks (for example, interest income and non- interest income) have been included in the data of the variable of our "output". A more detailed definition of the profit variable is included in Table 1.

\section{Other Control Variables}

\section{1) Corporate governance variables}

In our view, corporate governance structures are likely to affect the association between firm performance and pay dispersion (Ding et al. 2010; Zheng 2010). We therefore include the following two variables: “controlling ownership" and "CEO duality". 


\section{i. Controlling ownership}

We classify a bank as having a controlling owner if a shareholder has voting rights that sum to $10 \%$ or more; otherwise, we classify the bank as widely held. In previous research, it was argued that $10 \%$ voting rights are frequently sufficient to exert control (La Porta et al. 2002; and La Porta et al. 1998). While Caprio et al. (2004) use a $20 \%$ criterion, they still obtain the same conclusion as those who adopt $10 \%$ as their criterion. The principal shareholders of banks are themselves frequently financial institutions or corporate entities. Shleifer and Wolfenzon (2002) suggest that a marginal improvement in legal protection may have less of an impact on bank valuations when there is a controlling shareholder. We observe in our sub-sample of banks from developing countries that banks are not generally widely held.

ii. CEO duality:

We would like to include this variable in our major equation for examining whether the combined roles of the CEO and board chairman in the same person could weaken the positive association between firm performance and pay dispersion.

\section{2) Size}

By following prior studies focused on whether bank size may influence valuations and bank performance (Heffernan and Fu 2010; Hamilton et al. 2009; Caprio et al. 2004; Yu and Luu 2003), the size of the bank firm has also been adopted as our sole fixed factor in this translog profit function. The quantity of fixed inputs cannot be changed during the production period (one year, in this study). In this paper, all of the sample banks' sizes have been measured in US dollars.

\section{3) Capital Adequacy}

Tier 1 Capital is included in our model as one of the control variables to control for the impact from different regulatory restrictions on banks. Although most countries have indicated their intention to adopt the much more detailed set of recommendations contained in Basel II and III, not all of our sample countries adopted the Basel Committee's original recommendations on capital regulations and official supervision. Differences in Tier 1 capital ratios across these sample banks may also be a reflection of differences in regulatory restrictions on banks across countries.

\section{4) Legal origins}

Many studies investigate the effects of law and regulations for corporations (Chang et al. 2012; Jameson et al. 2000). To investigate the impact from different regulatory systems, we classify our sub-sample banks from developed-OECD countries according to the origin of their legal systems into two groups: "common law" vs "civil law". 
Legal origins are found to be indicative of the strength of investor protection. La Porta et al. (1998) and La Porta et al. (2002) find that shareholder rights are better protected in common law countries, promoting the development of financial markets and thus a market-based system. Conversely, Levine (1998) argues that civil law countries have well-developed banks and that their financial systems are more bank-based. Hence, legal origins can be seen as a proxy for the orientation of the financial system toward banks or markets. However, there is no one-to-one correspondence between legal tradition and financial systems. According to Ergungor (2004), legal tradition and prevailing economic conditions jointly determine whether a country is bank or market based.

\section{5) VIX index}

In addition to employing the conventional translog profit function and the pay-dispersion model as our combined theoretical model, we add the VIX index to our model specification as a macroeconomic variable to address market-wide volatility. The CBOE Volatility Index (VIX) is quoted in percentage points indicating the expected movement in the S\&P 500 index over the next 30-day period, which is then annualized. The VIX index is a widely used measure of market risk (Balasubramnian and Cyree 2011), showing market expectations of stock market volatility over the next 30-day period. For example, if the VIX is 18 , one can infer that the index option markets expect the S\&P500 to move up or down $18 \% / \sqrt{12}=5.20 \%$ over the next 30 -day period. We include the VIX index in our final module specification, equation (5), in order to control the changes in market conditions. The VIX index data in this study were obtained from Bloomberg.

Finally, we summarize our estimation methods for each variable and their definitions in Table 1.

\section{INSERT TABLE 1 HERE}




\section{Empirical results}

There has been a long-standing debate in the executive compensation literature as to whether higher or lower pay dispersion can enhance organizational performance. Moreover, there do not appear to be any published studies on examining these two competing management theories with a cross-country study. In this article, we first relate banks' performances to the executive pay dispersion by employing a group of cross-country sample banks. We empirically examine this question. Using a sample of 92 banks across 20 countries from 2004 to 2012, we aim to look at pay dispersion at the top executive level in order to test whether the tournament theory (favoring greater pay dispersion) or the equity fairness theory (arguing for smaller pay dispersion) is applicable to bank performance.

In this section, we report and interpret our empirical results.

\subsection{Data Sources and Sample Period}

The greatest challenge, and one of the contributions of the paper, is to generate the data of executive pay dispersion for each of our sample banks worldwide. Our original sample banks are chosen from the top 500 OECD (Organisation for Economic Co-operation and Development) banks. Our list of top 500 OECD banks is obtained from the Bankscope database and sorted by asset size. Only some of the sample banks can be included in this study, that is, if their relevant executive remuneration data are available from Thomson One databases or can be collected from their annual reports.

Next, we need to identify who were the key executive team members for this sample of banks by applying a similar coding method as Elkinawy and Stater (2011) and Bertrand and Hallock (2001) and making a complete rank-ordering of all of the titles in determining which title is the highest (see Table 2).

\section{INSERT TABLE 2 HERE}

We operate under the premise that the executive's title with the full company should supersede his/her title with a subsidiary or division. In this process, we estimate and review all managerial team members' annual pay information. For instance, for Chinese banks, we had to collect the relevant data of managerial team members' annual pay information from their annual reports because none of the relevant executive remuneration data were available from Thomson One databases. Based on the ranking of actual compensation, we select the five executives with the highest compensation in a year as the base for generating the pay dispersion variable for that sample year. Finally, based on the annual compensation 
dataset, we are able to generate the pay dispersion variable for each sample bank in each sample year by computing the mean and standard deviation of the compensation of the top three to five executives. The total annual compensation for each managerial team member is the total cash value of all pay components in that sample year, including salary, cash bonus, equity options and other compensations.

Through the selection processes mentioned above, our final sample is composed of 63 banks chosen from OECD countries and 29 banks from two developing countries: China (13 banks) and India (16 banks). Therefore, one contribution of this study is our own database of the key variable of executive pay dispersion. The complete list of banks can be found in Appendix A.

For the remainder of this study, we also classify our sub-sample banks from OECD countries into two groups: banks from common law countries and banks from civil law countries. The division of banks into these two groups is shown in Appendix B. In the following table, we summarize the descriptive statistics of the variables used in the study.

\section{INSERT TABLE 3 HERE}

We compute the mean and standard deviation of the compensation of the top three to five executives in each of our sample banks. Our mean dispersion (coefficient of variation) of management compensation is 0.3977 , with an interquartile range of 0.2839 , suggesting a considerably smaller sample cross-sectional variability in pay dispersion compared with the previous literature.

\subsection{Econometric procedure}

In the banking literature, fixed and/or random effects models are usually employed for panel data. In this study, we analyze our unbalanced panel data by employing the following econometric procedures. First, we examine our data using the likelihood ratio test. The null hypothesis of the likelihood ratio test is that the intercepts are the same for each bank and for each year. If this null hypothesis is accepted, our data can simply be pooled and panel least squares can be employed.

$y_{i t}=\alpha+\beta x_{i t}+u_{i t}+v_{i t}$

Where: $v_{i t} \sim N(0,1)$

$H_{0}=u_{1}=u_{2}=\ldots=u_{n}$ 
If this null is rejected, then it is not valid to impose the restriction that the intercepts are the same across all banks. Consequently, panel least squares cannot be adopted in this case. Rather, a panel approach-the fixed effects model or random effects model-must be employed. Second, we employ the Hausman test to decide whether the fixed effects model or random effects model suits our panel data better. The random effects approach has a major drawback in that it is valid only when the composite error term $w_{i t}$ is uncorrelated with all of the explanatory variables. The random effects panel model can be described below:

$$
\begin{aligned}
& y_{i t}=\alpha+\beta x_{i t}+w_{i t} \\
& w_{i t}=\varepsilon_{i}+v_{i t} \text { or } w_{i t}=\varepsilon_{t}+v_{i t}
\end{aligned}
$$

For the fixed effects model, it is possible to allow for both entity-fixed effects and time-fixed effects within the same model. The random effects could be along either the cross-sectional or period dimensions. However, because we have missing data in our dataset, we cannot have time variation and cross-section variation at the same time when the random effects model is employed in our study. The null hypothesis of the Hausman test is that both $\varepsilon_{i}$ and $v_{i t}$ are independent of all of $x_{i t}$. If this null hypothesis of the Hausman test is accepted, $\varepsilon_{i}, v_{i t}$ and all of the $x_{i t}$ are uncorrelated, and therefore, a random effects approach can be used. Otherwise, if the null of the Hausman test is rejected, we would employ the fixed effects model.

For all five groups defined earlier, we repeat the same econometric procedures described above. All of the relevant econometric procedures for each sample group have been summarized in the following tables, which report the key empirical results. Overall, we find that the time-fixed effect model suits most of our data better. This finding is consistent with the arguments put forward by Brooks (2008), that the random effects model is more appropriate when the sample entities have been randomly selected from the population. Moreover, we adopt the White diagonal, which is robust to heteroskedasticity, as our coefficient covariance method (Reed and Ye 2011).

To examine whether the time-fixed effect can capture the variation of macro factors over time in our unbalanced panel data, we carry out the following robustness check in this study. We compare the regression results for equation (5) with and without adding the VIX index as a control variable. This robustness check is performed for each sample group. We find supporting evidence that our time-fixed effect can sufficiently capture the variation of macro factors over time, as proxied by the VIX index. 


\subsection{Results}

We examine the association between pay dispersion and bank performances by employing equation (5) across the following five groups: (a) worldwide, (b) developing, (c) developed, (d) civil law and (e) common law. The econometric procedures described in the previous section are adopted. Furthermore, to test whether executive pay dispersion may have a (statistically) significant impact on bank performance and to determine whether it shapes the relationship with bank performance in a linear or quadratic way, Wald tests are carried out on two corresponding estimated coefficients: "the linear term of executive pay dispersion" and "the quadratic term of executive pay dispersion". The following six tables (from Tables 4 to 9) report our empirical results for each of our sub-sample banks. Finally, to better visualize our key regression results, we present Figures 1 through 5, showing the relationship between our two key variables: executive pay dispersion and banking firm performance. The figure is only included if the following two conditions are met: (a) the coefficients of executive pay dispersion variables (the linear term and/or the quadratic term) are statistically significant, and (b) the regression residuals are normal, indicating our model is wellspecified for this sub-sample.

First, we pool all of our sample banks together. The regression result on all sample banks, named "worldwide", is summarized in Table 4. Although the adjusted $R^{2}$ on this regression seems reasonable, ranging from $66.26 \%$ to $87.18 \%$, we observe that the residuals of these regressions are not normally distributed. The problem of residual distribution indicates that it may not be appropriate to pool all of our sample banks. To solve this problem, we divide our sample into two smaller sub-samples: developing (banks in developing countries) and developed (banks in developed countries). This revision in our sample choice is also supported by Table 5, which reports the descriptive statistics of the key variable-executive pay dispersion - across our sub-sample groups. Table 5 shows that the average pay dispersion of "developing countries" is 0.2515 , which is much smaller than the average pay dispersion of "developed countries" at 0.4673 .

\section{INSERT TABLE 4 HERE}

\section{INSERT TABLE 5 HERE}

In the second step, we examine our sub-sample of developing country banks, which is composed of 29 financial institutions from China and India. The empirical results for the sub-sample of developing country banks are reported in Table 6. We find that the residual distributions of these regressions are normal for the $\log$ (profit) indicator only. Table 6 shows that when $\log$ (profit) is adopted as the bank performance indicator, the coefficient of the quadratic term of pay dispersion is negative and significant at the $1 \%$ level, providing supporting evidence of the equity fairness theory for our sample banks in developing countries. The 
relationship between the variable of executive pay dispersion and the $\log$ (profit) indicator is also depicted in Figure 1. Our empirical results can be interpreted as implying that greater pay dispersion has a negative impact on bank performance in China and India.

\section{INSERT TABLE 6 HERE \\ INSERT FIGURE 1 HERE}

The previous Table 5 shows that the average executive pay dispersion of our sub-sample of developing country banks is 0.2515 . Moreover, we observe that total executive compensation in this sub-sample is mostly composed by salary and the cash bonus. We can conclude that the theory of equity fairness can explain the impact of executive pay dispersion on bank performance in this group.

Next, we analyze the remaining 63 sample banks from developed countries. Table 7 shows that the adjusted $\mathrm{R}^{2}$ for these regressions ranges from $76.61 \%$ to $78.19 \%$. All of the residual distributions of these regressions for the three performance indicators are normal, indicating that our model is well-specified. For this sub-sample, we find that the linear term and the quadratic terms of pay dispersion are statistically significant for the two indicators of market valuation: the P/B ratio and the Tobin's Q ratio.

\section{INSERT TABLE 7 HERE}

The relationship between executive pay dispersion and these two market-related bank performance indicators is depicted in Figures 2 and 3. Both sets of empirical results for Tobin's Q and the P/B ratio can be interpreted as supporting evidence of equity fairness, except for very high pay dispersion (U-shaped impact curve). Although the tournament theory is corroborated for extremely high pay dispersion, our previous Table 5 shows that the average of pay dispersion in developed countries is 0.4673 , placing it on the left-hand side of the U-shaped curve, indicating greater overall validity for the equity fairness theory.

\section{INSERT FIGURE 2 HERE}

\section{INSERT FIGURE 3 HERE}

Now, we are curious as to what may be driving this result. Therefore, we separate the developed country sub-sample into two smaller groups: a group of civil law countries and a group of common law countries. The previous Table 5 shows that the average pay dispersion of the sub-sample of common law countries is 
0.5016, which is slightly higher than the average pay dispersion of the sub-sample of civil law countries at 0.4274. The empirical results of the common law group are reported in Table 8 below.

\section{INSERT TABLE 8 HERE}

Table 8 shows that the adjusted $\mathrm{R}^{2}$ values range from $82.79 \%$ to $85.87 \%$, while the residuals for all of the regressions are normally distributed as well. The linear and quadratic terms of pay dispersion have no impact on the three bank performance indicators. Based on these empirical findings, we can conclude that for the sample banks in the common law countries, neither the tournament theory nor the equity fairness theory is applicable to the relationship between executive pay dispersion and banks' performance.

Finally, we study banks from the civil law countries. Table 9 reports that the regression residuals are normal for the two indicators of market valuation, the $\mathrm{P} / \mathrm{B}$ and Tobin's $\mathrm{Q}$ ratios, with the adjusted $\mathrm{R}^{2}$ ranging from $85.35 \%$ to $90.45 \%$. This may imply that our model is well-specified when the impact of executive pay dispersion on bank performance is based on the view of market valuation in this sub-sample of the civil law countries. Moreover, the linear term and the quadratic terms of pay dispersion are statistically significant for the two market valuation indicators.

\section{INSERT TABLE 9 HERE}

As before, we visualize the relationship between the variable of executive pay dispersion and these two indicators of the market valuation in Figures 4 and 5. The results for the Tobin's Q and P/B ratios can be interpreted as supporting evidence of equity fairness, except for very high pay dispersion (U-shaped impact curve). Regarding civil law countries, very high pay dispersion is beneficial to bank performance. However, on average, pay dispersion in civil law countries is 0.4274 (see Table 5) and is on the left-hand side of the U-shaped curve. This lends support to the equity fairness theory for most observed values of pay dispersion.

INSERT FIGURE 4 HERE

INSERT FIGURE 5 HERE 


\section{Robustness Checks}

In this study, we use entity and time-fixed or random effect regression to rule out the impact of potential unobservable time-invariant firm-specific and year-specific effects. Here, we examine whether our timefixed effect can also capture the variation of macro factors over time by adding the VIX index to our regressions. This robustness check is tested for all of our sub-samples. In this section, we show the robustness check analyses on the sub-sample of common law banks and the sub-sample of developing banks as our two illustrated examples.

We address market-wide volatility by adding the VIX index to the model specification (equation 5) as a macro control variable (Balasubramnian and Cyree 2011). Overall, our empirical results of the likelihood ratio test and the Hausman test indicate that the time-fixed effect model is the preferred method of estimation for most of our sub-sample groups in this study. When the time fixed-effect model is adopted, the intercepts of our major equation (5) are allowed to vary over time but are assumed to be the same across entities at each given point in time.

$$
y_{i t}=\alpha+\beta x_{i t}+\lambda_{t}+v_{i t}
$$

Where $\lambda_{t}$ is a time-varying intercept that captures all of the variables that affect $y_{i t}$ and that vary over time but are constant cross-sectionally.

We find that the problem of a near singular matrix arises as soon as the VIX index is added as an additional variable to our original regression, i.e., the time-fixed effect model would have to be abandoned. The near singular matrix problem may be caused by the nature of the VIX index data because all 92 banks worldwide have nine identical annual values from 2004 to 2009. Therefore, to some degree, the VIX index offers a similar function as a time dummy variable. To examine our assumption, we re-estimate our model specification from equation (5), with a simple time dummy for each sample year starting from 1 to 9 for our sample period $2004-2012$.

The sub-sample of common law banks is used as an example. Table 10 summarizes the three empirical results of the common law banks, showing the relationship between the bank performance indicator, namely, Tobin's Q, and executive pay dispersion. In Table 10, these three regression results are classified as: (1) with the time-fixed effect model only, (2) with the VIX index only and (3) with a simple time dummy only. 


\section{INSERT TABLE 10 HERE}

Table 10 shows consistent empirical results across the three equations. The coefficient values of the VIX index and the time dummy variable are very similar. Both variables are also negative and statistically significant at the $1 \%$ level. However, the residual of the model specification with the VIX index is not normally distributed. Therefore, for a better specified model, the VIX index should be omitted from our major equation, and we should use either the first regression with the time-fixed effect model only or the third regression with a simple time dummy only.

With the time-fixed effect model, a slightly higher adjusted $R^{2}(85.87 \%)$ is obtained compared with that based on the regression with the time dummy only (79.12\%). Based on these results, we conclude that the time-fixed effect regression is able to capture the variation of macro factors over time, which may be viewed as part of potential unobservable year-specific effects.

Another illustrative example is based on our sub-sample of developing country banks. The regressions for this sub-sample with and without the VIX index are shown in Table 11. The coefficients of the VIX index are not statistically significant on these regressions, irrespective of which of the three bank performance indicators is adopted. Moreover, the residuals of the two regressions of the Tobin's Q and P/B ratios are not normally distributed, and their overall fit (measured by the values of adjusted $R^{2}$ ) are reduced dramatically.

\section{INSERT TABLE 11 HERE}

Finally, a comparison of these regression results with and without the VIX index for our sub-sample of developing country banks, as shown in Table 11, yields further supporting evidence that our time-fixed effects have captured the variation of macro factors over time. Based on these robustness checks, we can conclude that our empirical results, shown from Tables 4 to 11, are robust and consistent.

\section{Summary of our regression results across our five groups}

The empirical results for all five sub-sample groups are summarized in Table 12. We find supporting evidence of the equity fairness theory in civil law country banks. In our subsample of civil law countries, where bank performance was measured by either the Tobin's Q ratio or the P/B ratio, the overall impact of executive pay dispersion is mostly negative, and there is a non-linear effect because banks would perform best when there is either very low or very high executive pay dispersion. For the developing country sample 
banks in China and India, the empirical results of the profit indicator also show that greater executive pay dispersion has a negative impact on bank profit. The theory of equity fairness can also explain the impact of executive pay dispersion on bank performance in this group.

\section{INSERT TABLE 12 HERE}

\section{Other Control Variables}

Some of the control variables in our pay dispersion model are also important in determining banks' performance. Across our five sample groups, the variable of default risk provides a consistently significant negative impact on the bank performance indicators. Another interesting finding is that being "widely owned", which indicates that no shareholder owns more than $10 \%$, yields a positive impact on bank performance for our developed country sample banks. This is consistent with the result obtained by Caprio, Laeven and Levine (2004). They suggest that stronger legal protection of shareholders is related to countries having more widely held and better-performing banks. Conversely, being widely owned has a negative impact on bank performance for our sample of developing country banks (China and India). This finding is similar to that of Claessens and Djankov (1999), who investigate a cross-section of Czech firms over the period 1992-1997. In transition economies with more uncertain shareholder protection, a more concentrated ownership leads to higher firm profitability and labor productivity. This may explain why the "widely owned" variable has opposite effects on banking firm performance for developing and developed country banks in our sample.

CEO duality is another governance variable that we include. A policy introduced by the China Banking Regulatory Commission (CBRC) in 2005 states that the chairman and president roles should not be assumed by the same person. This policy has put an end to the era where the bank president alone took charge of the whole bank. There were a total of 17 listed banks in China, and a total of 16 banks were listed in the domestic A-share market at the end of 2012. However, we found that for our sub-sample of developing countries, China and India, the variable of CEO duality has no impact on the three bank performance indicators. 


\section{Conclusion}

In this study, we investigate the relationship between executive pay dispersion and bank performance by testing two competing theories, the tournament theory (which favors a hierarchical wage structure) and the equity fairness theory (supporting a compressed wage structure). The main contributions of this paper to the literature are threefold. First, unlike most of the pay dispersion literature, which has relied on reduced-form models, we propose a structural model that combines two elements: (1) a pay dispersion model and (2) a modified translog profit function applied to the banking industry that is commonly used to estimate economies of scale and efficiency. The translog profit function is based on microeconomic theory and models bank performance as a function of (1) the prices of bank outputs, (2) the prices of bank inputs and (3) the quantities of fixed factors. This is a significant and justifiable departure from the common practice of regressing bank performance against somewhat arbitrary lists of explanatory variables, including executive pay variables. We infer that the previously employed reduced-form models in the literature can be viewed as one of the special cases of our proposed theoretical model. The variables featured in a conventional translog profit function play an important role as control variables when we investigate the relationship between executive pay dispersion and bank performance. The model we adopt in this study-a combination of the pay dispersion model with a translog profit model—give us a very good $\mathrm{R}^{\wedge} 2$ of more than $80 \%$. Econometric specification tests, including normality tests of the residuals, indicate that the model is well-specified.

Second, most of the management literature has excluded banks from their samples because financial institutions have different characteristics from other industries. However, the need for research into compensation in banks has become more visible recently. Our second main contribution is in creating and employing a unique dataset that ranges from 2004 to 2012 and includes estimating relevant pay dispersion variables for 92 sample banks across 18 developed countries in the OECD and two developing countries, China and India. Our paper also contributes to the executive pay literature as a comparative study across countries; such studies are rare.

Furthermore, we study whether differences between countries that are proxied by the level of capital market development and legal system influence the relationship of pay disparity and bank performance. In our subsample of civil law countries, where bank performance was measured by either Tobin's Q or the P/B ratio, the overall impact of executive pay dispersion is mostly negative, and we find supporting evidence of the equity fairness theory, except for very high levels of dispersion. There is a non-linear effect, as banks would perform best when there is either very low or very high executive pay dispersion. However, because 
the average pay dispersion in civil law countries is on the left-hand side of the U-shaped curve (see Table 5), this lends support to the equity fairness theory for most observed values of pay dispersion in civil law countries. This U-shaped effect of executive pay dispersion in this sub-sample is also found in German professional soccer teams (Franck and Nuesch 2011), where medium levels of pay dispersion result in the weakest team performance. In our subsample of developed common law countries, however, we find no evidence of a significant impact of pay dispersion on bank performance.

For the developing country sample banks in China and India, the empirical results of the profit indicator also show that greater executive pay dispersion has a negative impact on bank profit. The theory of equity fairness can also explain the impact of executive pay dispersion on bank performance in this group.

Based on our empirical evidence, we conclude that in developing economies and economies that are classified as civil law countries, the costs from envy and dysfunctional behavior associated with larger pay dispersion under the theory of equity fairness exceed the tournament incentives and motivational benefits from larger pay dispersion under the tournament theory. Lower pay dispersion, a proxy for teamwork, is mostly effective in enhancing bank performance in a significant section of sample banks, i.e., civil law and the developing countries China and India. 


\section{References}

Aggarwal R, Samwick A (1999) The Other Side of the Trade-off: The Impact of Risk on Executive Compensation. J Polit Econ 107: 65-105.

Aggarwal R, Samwick A (2003) Performance incentives within firms: the effects of managerial responsibility. J Financ 58: 161350 .

Akerlof GA, Yellen, JL (1988) Fairness and Unemployment. Am Econ Rev 78: 44-49.

Akerlof GA, Yellen, JL (1990) The Fair Wage-Effort Hypothesis and Unemployment. Q J Econ 105: 255-83.

Akhavein, JD, Berger AN, Humphrey DB (1997) The Effects of Megamergers on Efficiency and Prices: Evidence from a Bank Profit Function. Rev Ind Organ, 12: 95-139.

Balasubramnian B, Cyree KB (2011) Market discipline of banks: Why are yield spreads on bank-issued subordinated notes and debentures not sensitive to bank risks? J Bank Financ 35: 21-35.

Barron J, Waddell G (2003) Executive rank, pay and project selection. J Financ Econ, 67: 305-349.

Barth, J, Caprio, G, Levine, R (2004) Bank Supervision and Regulation: What Works Best? J Financ Intermed, 13: $205-248$.

Beaumont PB, Harris, RID (2003) Internal Wage Structure and Organisational Performance, Brit J Ind Relat 41:53-70.

Becht M, Bolton P, Röell A (2011) Why bank governance is different. Oxford Rev Econ Pol 27: 437-463

Beck, T, Demirguec-Kunt, A, Levine R. (2003) Bank supervision and corporate finance, NBER Working Paper 9620, Cambridge, MA: National Bureau of Economic Research.

Becker BE, Huselid MA (1992) The Incentive Effects of Tournament Compensation Systems. Admin Sci Quart 37: $336-350$.

Berger AN, Hancock D, Humphrey DB (1993) Bank efficiency derived from the profit function. J Bank Financ 17: $317-347$.

Blackwell D, Dudney D, Farrell K (2007) Changes in CEO compensation structure and the impact on firm performance following CEO turnover, Rev Quant Financ Accounting 29: 315-338.

Brooks, C (2008) Introductory Econometrics for Finance. Cambridge: Cambridge University Press

Bryan S, Hwang L, Lilien S (2000) CEO stock-based compensation: an empirical analysis of incentive intensity, relative mix and economic determinants. J Bus 73: 661-693.

Burkart M, Gromb D, Panunzi, F (1998) Why high takeover premia protect minority shareholders, J Pol Econ, 106: $172-204$.

Caprio, G, Laeven, L, Levine, R (2007) Governance and Bank Valuation. J Financ Intermed 16: 584-617

Chang H, Hiu C, Wan KM (2012) Effect of the Sarbanes-Oxley act on CEOs' stock ownership and pay-performance sensitivity, Rev Quant Financ Accounting 38: 177-207.

Chen, J, Ezzamel, M, Cai, Z (2011) Managerial Power Theory, Tournament Theory and Executive Pay in China. J Corp Financ 17: $1176-99$.

Cheung J, Corrado C (2009) Valuation and incentive effects of hurdle rate executive stock options, Rev Quant Financ Accounting 32: $269-285$.

Claessens S, Djankov S (1999) Ownership Concentration and Corporate Perfor-mance in the Czech Republic, J Compar Econ 27: 498-513.

Conyon, MJ and Murphy, KJ (2000) The Prince and the Pauper? CEO Pay in the Untited States and United Kingdom. Econ J 110: 640-671.

Cowherd DM, Levine DI (1992) Product quality and pay equity between lower-level employees and top management. Admin Sci Quart 37:302-30.

Diewert WE (1973) Functional Forms for Profit and Transformation Functions. J Econ Theory, 6: 284-316. 
Ding S, Wu Z, Li Y, Jia C (2010) Executive compensation, supervisory board, and China's governance reform: a legal approach perspective, Rev Quant Financ Accounting 35: 445-471.

Drago RW, Garvey GT (1998) Incentives for helping on the job: theory and evidence. J of Labor Econ 16: 1-15.

Ehrenberg RG, Bognanno ML (1990) Do Tournaments Have Incentive Effects? J Pol Econ 98:1307-24.

Elkinawy S, Stater M (2011) Gender differences in executive compensation: Variation with board gender composition and time, J

Econ Bus 63: 23-45.

Ergungor OE (2004) Market- vs. bank-based financial systems: Do rights and regulations really matter? J Banking Finance 28: 2869-2887.

European Central Bank (2010) Beyond ROE:How to measure bank performance. ECB: Frankfurt.

Franck E, Nüesch S (2011) The effect of wage dispersion on team outcome and the way team outcome is produced. Appl Econ 43: 3037-3049.

Grund C, Westergaard-Nielsen N (2008) The Dispersion of Employees' Wage Increases and Firm Performance. Ind Labor Relat Rev 61: 485-501.

Hall B, Liebman J (1998) Are CEOs Really Paid Like Bureaucrats? Quart J Econ 113: 653-91.

Hamilton J, Rahman S, Lee AC (2009) EVA:: Does Size Matter? Rev Pacific Basin Finan Markets Pol, 12: $267-287$.

Hausman JA (1978) Specification tests in econometrics. Econometrica 46: 236-55.

Heffernan SA, Fu X (2010) Determinants of financial performance in Chinese banking. Appl Financial Econ, 20: $1585-1600$. Heyman F (2005) Pay inequality and firm performance: evidence from matched employer-employee data, Appl Econ, 37: 13131327.

Hibbs, DA, Locking, H (2000) Wage dispersion and Productive Efficiency: Evidence for Sweden, J Labor Econ, 18: 755 -782. Himmelberg C, Hubbard R, Palia D (1999) Understanding the determinants of managerial ownership and the link between ownership and performance. J Financial Econ 53:353-384.

Jameson M, Sullivan MJ, Constand R. (2000) Ownership Structure and Performance of Japanese Firms: Horizontal Keiretsu, Vertical Keiretsu, and Independents, Rev Pacific Basin Finan Markets Pol, 3: 535-556.

Kale JR, Reis E, Venkateswaran V (2009) Rank-order Tournament and Incentive Alignment: the Effect on Firm Performance, J Finance 64:1479-1512.

La Porta R, Lopez-de-Silanes F, Shleifer A (2002) Government ownership of banks, J Financ, 57: 1147-1170.

La Porta R, Lopez-de-Silanes F, Shleifer A, Vishny RW (1998) Law and finance, J Pol Econ, 106: 1113-1155.

La Porta R, Lopez-de-Silanes F, Shleifer A, Vishny RW (2002) Investor Protection and Corporate Valuation, J Finance, 57: 11471170 .

Lambert R, Larcker D (1987) An analysis of use of accounting and market measures of performance in executive compensation contracts. J Accounting Res 25: 85-125.

Lazear EP, Rosen S (1981) Rank-order tournaments as optimum labor contracts. J Pol Econ 89: 841-64.

Lazear, EP (1989) Pay equality and industrial politics, J Pol Econ 97: 561-580.

Lee KW, Lev B, Yeo GHH (2008) Executive pay dispersion, corporate governance, and firm performance, Rev Quant Financ Accounting 30: 15-338.

Lee KW, Lee CF (2009) Cash Holdings, Corporate Governance Structure and Firm Valuation, Rev Pacific Basin Finan Markets Pol, 12: 475-508.

Levine DI (1991) Cohesiveness, Productivity and Wage Dispersion. J Econ Behav Organ 15:237-55.

Levine, R (1998) The legal environment, banks, and long-run economic growth, J Money Credit Banking 30, 596-620.

Main B, O’Reilly CA, Wade J (1993) Top executive pay: tournament or team work? J Labor Econ 11: 606-28. 
Marshall, J (2009) Executive Remuneration in UK Banking ( No. SN/BT/04970), House of Commons Library.

McFadden D (1966) Cost, Revenue, and Profit Functions: A Cursory Review. Working Paper No. 86, Institute of Business and Economic Research, University of California.

Mehran H, Morrison A, Shapiro J (2011) Corporate Governance and Banks: What Have We Learned from the Financial Crisis?, Federal Reserve Bank of New York Staff Report no. 502.

Milgrom PR, Roberts J (1992) Economics, organizations, and management. Prentice-Hall, Englewood Cliffs.

Milgrom, PR (1988) Employment contracts, influence activities and efficient organization designs. J Pol Econ 96:42-60.

Milkovich, GT, Newman, JM (1999) Compensation, McGraw Hill, Boston/Irwin.

Mullineaux, DJ (1978) Economies of scale and organizational efficiency in banking: a profit-function approach, J Financ, 33: 259280 .

Murphy KJ. (1999) Executive Compensation. In: Ashenfelter, O, Card, D (eds) Handbook of Labor Economics, Vol. 3b. Elsevier Science North Holland: New York and Oxford, pp. 2485-2563.

O’Reilly C, Main B, Crystal G (1988) CEO compensation as tournament and social comparison: a tale of two theories, Admin Sci Quart 33: 257-274

Pfeffer J, Leangton N (1993) The effect of wage dispersion on satisfaction, productivity and working collaboratively: evidence from college and university faculty, Admin Sci Quart 38: 382-407.

Reed WR, Haichun, Y (2011) Which panel data estimator should I use? Applied Economics 43: 985-1000.

Shleifer A, Wolfenzon, D (2002) Investor protection and equity markets, J Financ Econ, 66: 3-27.

Wade JB, O'Reilly CA, Pollock TG (2006) Overpaid CEOs and Underpaid Managers: Fairness and Executive Compensation. Organ Sci 17: 527-44.

Wooldridge, JM (2002) Econometric analysis of cross section and panel data. MIT Press: Cambridge/ London.

Yotopoulos PA, Lau LJ (1973) A Test for Relative Economic Efficiency: Some Further Results. Amer Econ Rev, 63: $214-230$. Yu P, Luu BV (2003) Banking mergers: the impact of financial liberalisation on the Taiwanese banking industry, Rev Quant Financ Accounting 20: 385-413.

Zheng Y (2010) Heterogeneous institutional investors and CEO compensation, Rev Quant Financ Accounting 35: 21-46. 


\section{Acknowledgements}

We appreciate the helpful comments received from two anonymous referees, the editor (Professor ChengFew Lee), and seminar participants at the $6^{\text {th }}$ IFABS Conference in Lisbon. Moreover, we would like to thank Craig Moorcroft, Terry Parker and Zhenhua Wang for their kind support in collecting data. 


\section{Tables}

Table 1 Definitions of variables in our model and their estimation methods

\begin{tabular}{|c|c|}
\hline Variable & Definition \\
\hline \multicolumn{2}{|l|}{ Pay dispersion indicators } \\
\hline (paydisp) & In this study, we adopt the coefficient of variation $(\mathrm{CV})$ as the indicator of the pay dispersion. \\
\hline (paydisp) $^{2}$ & The coefficient of variation (CV) squared has also been included. \\
\hline \multicolumn{2}{|c|}{ Banking firms' performance indicators } \\
\hline Total profit & $\begin{array}{l}\text { The variable of profit is defined as total revenue minus the cost of the variable factors of } \\
\text { production. }\end{array}$ \\
\hline Pre-tax profit margin & Pre-tax profit margin $=[$ Pretax Income $($ Losses $)] /($ Net Revenue $)$ \\
\hline Return on Equity (ROE) & $\mathrm{ROE}=$ (net income available for common shareholders) / (average total common equity) \\
\hline Tobin's Q & $\begin{array}{l}\text { Tobin's } \mathrm{Q}=\text { (market capitalization }+ \text { liabilities }+ \text { preferred equity }+ \text { minority interest }) / \text { (total } \\
\text { assets) }\end{array}$ \\
\hline $\mathrm{P} / \mathrm{B}$ ratio & $\mathrm{P} / \mathrm{B}$ ratio $=($ share price $) /($ book value per share $)$ \\
\hline \multicolumn{2}{|l|}{ Output prices } \\
\hline Output & $\begin{array}{l}\text { Output = (all income) / (earning assets }) \\
\text { All the incomes generated by banks have been included in the data of income. For example: } \\
\text { interest income and non-interest income. The definition of our "Output" is as follows: Output = } \\
\text { [(interest income })+(\text { investment income })] / \text { (marketable securities })+(\text { short term } \\
\text { securities })+(\text { total loans)+(interbank assets)+(long term investments and long-term receivables) }\end{array}$ \\
\hline \multicolumn{2}{|l|}{ Input prices } \\
\hline Labor price & $\begin{array}{l}\text { In this study, we define the factor of labor price as the average wage rate of bank officers. } \\
\text { Labor input price }=\text { (personnel expense }) /(\text { number of employees })\end{array}$ \\
\hline Interest input price & $\begin{array}{l}\text { Interest price } \\
=(\text { Interest expense }) /(\text { average interest bearing liabilities })\end{array}$ \\
\hline \multicolumn{2}{|l|}{ Quantities of fixed factors } \\
\hline Bank size & The logarithm of each bank's total assets \\
\hline \multicolumn{2}{|l|}{ Control variables } \\
\hline \multirow[t]{2}{*}{ Corporate governance factors } & $\begin{array}{l}\text { Widely owned } \\
\text { We define controlling ownership as being present when a shareholder owns more than } 10 \% \text {, } \\
\text { otherwise the bank is widely owned. } \\
\text { widely owned = } 1 \text {, } \\
\text { otherwise controlling ownership is present, not widely owned = } 0\end{array}$ \\
\hline & $\begin{array}{l}\text { CEO duality } \\
\text { In this study, we assume that if CEO and Chairman are different }=1 \text {, otherwise the same }=0 \text {. }\end{array}$ \\
\hline Capital adequacy & Tier 1 capital ratio = Tier 1 capital / risk-weighted assets. \\
\hline Default risk & Default risk $=($ Non-performing asset $) /($ total assets $)$ \\
\hline $\begin{array}{l}\text { Dummy variable for } \\
\text { development status }\end{array}$ & $\begin{array}{l}\text { A group for Developed Countries }=1 \\
\text { A group for Developing Countries }=0\end{array}$ \\
\hline
\end{tabular}


Table 2 Rank-ordering from High to Low

\begin{tabular}{|l|l|}
\hline & Rank-ordering from High to Low \\
\hline 1 & CEO /Chair \\
\hline 2 & Vice Chair \\
\hline 3 & President \\
\hline 4 & Chief Financial Officer (CFO) \\
\hline 5 & Chief Operating Officer (COO) \\
\hline 6 & Other “Chief” officer \\
\hline 7 & Executive Vice President \\
\hline
\end{tabular}


Table 3 Descriptive statistics of all variables (Currency: US dollar)

\begin{tabular}{|c|c|c|c|c|c|c|}
\hline & $\begin{array}{l}\text { Abbreviation of } \\
\text { variable }\end{array}$ & Mean & Median & Maximum & Minimum & $\begin{array}{l}\text { Standard } \\
\text { deviation }\end{array}$ \\
\hline $\begin{array}{l}\text { Bank asset size } \\
\text { (measurement unit: million } \\
\text { US dollars) }\end{array}$ & Size & 597572.2 & 290816.7 & 3649800 & 4136.773 & 724035.3 \\
\hline Pre-tax profit & Profit & 4718.660 & 2200.030 & 48923.34 & 13.23800 & 6431.091 \\
\hline Interest price $(\%)$ & Interest & 4.087504 & 3.689700 & 20.33500 & 0.589900 & 2.141603 \\
\hline Default risk (\%) & Defaultr & 1.912710 & 0.886850 & 34.82890 & 0.000000 & 3.186683 \\
\hline Output & Output & 0.048843 & 0.044700 & 0.192053 & 0.007140 & 0.020660 \\
\hline $\begin{array}{l}\text { Capital adequacy - Tier } 1 \\
\text { capital ratio }(\%)\end{array}$ & Tier1 & 9.855876 & 9.310000 & 32.00000 & -1.470000 & 3.118807 \\
\hline Labor price & Laborp & 0.084283 & 0.073436 & 0.504750 & 0.005875 & 0.072025 \\
\hline ROE & Roe & 11.88407 & 14.12185 & 42.32480 & -156.5255 & 14.27658 \\
\hline Pretax profit margin $(\%)$ & pretaxmargin & 22.11411 & 28.11740 & 85.26910 & -535.5368 & 40.55895 \\
\hline Tobin's Q & Tobinq & 1.030052 & 1.017750 & 1.619800 & 0.941800 & 0.061815 \\
\hline $\mathrm{P} / \mathrm{B}$ ratio & $\mathrm{Pb}$ & 1.549660 & 1.333900 & 8.127300 & 0.024800 & 1.065410 \\
\hline VIX index & VIX & 20.80083 & 18.02333 & 31.79333 & 12.55000 & 7.362375 \\
\hline Pay dispersion & Paydisp & 0.397701 & 0.345394 & 1.459283 & 0.000000 & 0.283854 \\
\hline
\end{tabular}


Table 4 Performance regression results - All sample banks ( 92 banks)

\begin{tabular}{|c|c|c|c|}
\hline Performance indicators & Log(Profit) & Tobin's Q & $\mathbf{P} / \mathbf{B}$ \\
\hline $\mathrm{C}$ & $\begin{array}{l}-19.3744 * * * \\
(6.5659)\end{array}$ & & \\
\hline paydisp & $\begin{array}{l}0.0320 \\
(0.4423)\end{array}$ & $\begin{array}{l}-0.0522 * \\
(0.0269)\end{array}$ & $\begin{array}{l}-0.6964 * \\
(0.3873)\end{array}$ \\
\hline (paydisp) $^{2}$ & $\begin{array}{l}0.1141 \\
(0.3843)\end{array}$ & $\begin{array}{l}0.0381 * \\
(0.0222)\end{array}$ & $\begin{array}{l}0.4654 \\
(0.3101)\end{array}$ \\
\hline $\log ($ output $)$ & $\begin{array}{l}-7.0176 * * * \\
(2.3476)\end{array}$ & & \\
\hline \multicolumn{4}{|l|}{$\log ($ interestp/100) } \\
\hline \multicolumn{4}{|l|}{$\log ($ laborp) } \\
\hline $\log ($ size $)$ & $\begin{array}{l}2.0472 * * * \\
(0.7675)\end{array}$ & $\begin{array}{l}0.1053 * * * \\
(0.0330)\end{array}$ & $\begin{array}{l}1.9677 * * \\
(0.7856)\end{array}$ \\
\hline $0.5 * \log ($ output $) * \log ($ output $)$ & & $\begin{array}{l}0.1386 * * * \\
(0.0425)\end{array}$ & $\begin{array}{l}1.1912 * \\
(0.6733)\end{array}$ \\
\hline \multicolumn{4}{|c|}{$0.5 * \log ($ interestp $/ 100) * \log ($ interestp/100) } \\
\hline $0.5 * \log ($ laborp $) * \log ($ laborp $)$ & & $\begin{array}{l}-0.0204 * * \\
(0.0090)\end{array}$ & $\begin{array}{l}-0.2612 * * * \\
(0.0765)\end{array}$ \\
\hline $0.5 * \log ($ size $) * \log ($ size $)$ & & $\begin{array}{l}-0.0080 * * * \\
(0.0022)\end{array}$ & $\begin{array}{l}-0.1625 * * * \\
(0.0581)\end{array}$ \\
\hline $\log (\text { output })^{*} \log ($ interestp/100) & $\begin{array}{l}-0.8379 * * \\
(0.4197)\end{array}$ & $\begin{array}{l}-0.0585^{* * *} \\
(0.0190)\end{array}$ & \\
\hline $\log ($ output $) * \log ($ laborp $)$ & $\begin{array}{l}-0.8454 * * * \\
(0.3240)\end{array}$ & & \\
\hline \multicolumn{4}{|l|}{$\log ($ output $) * \log ($ size $)$} \\
\hline $\log ($ interestp/100)*log(laborp) & & $\begin{array}{l}0.0405 * * * \\
(0.0118)\end{array}$ & $\begin{array}{l}0.6876^{* * * *} \\
(0.1917)\end{array}$ \\
\hline \multicolumn{4}{|l|}{$\log ($ interestp/100)*log(size $)$} \\
\hline $\log ($ laborp $) * \log ($ size $)$ & $\begin{array}{l}-0.1809 * * * \\
(0.0561)\end{array}$ & & \\
\hline Widelyown & $\begin{array}{l}0.2071 \text { *** } \\
(0.0660)\end{array}$ & $\begin{array}{l}0.0083 * \\
(0.0044)\end{array}$ & $\begin{array}{l}0.1043 * \\
(0.0554)\end{array}$ \\
\hline \multicolumn{4}{|l|}{ Ceodual } \\
\hline Developed & $\begin{array}{l}-0.5272 * * * \\
(0.1661)\end{array}$ & & \\
\hline (defaultr/100) & $\begin{array}{l}-15.8737 * * * \\
(4.3276)\end{array}$ & $\begin{array}{l}-0.6554 * * * \\
(0.1252)\end{array}$ & $\begin{array}{l}-10.7155^{* * *} \\
(0.7371)\end{array}$ \\
\hline$($ tier1/100) & & $\begin{array}{l}0.2848 * * \\
(0.1335)\end{array}$ & \\
\hline *Wald test & $\checkmark$ & $\checkmark$ & $\checkmark$ \\
\hline
\end{tabular}




\begin{tabular}{|c|c|c|c|}
\hline $\begin{array}{l}\text { The null hypothesis assumes that the coefficients of (paydisp) and } \\
\text { (paydisp) }{ }^{2} \text { are zero }\end{array}$ & & & \\
\hline Residual & residual not normal & $\begin{array}{l}\text { residual not } \\
\text { normal }\end{array}$ & $\begin{array}{l}\text { residual not } \\
\text { normal }\end{array}$ \\
\hline \multicolumn{4}{|l|}{ Our econometric procedures are shown below: } \\
\hline Time fixed effect & $\checkmark$ & $\checkmark$ & $\checkmark$ \\
\hline Bank fixed effect & $\cdot$ & $\cdot$ & $\cdot$ \\
\hline Fixed (both) & $\cdot$ & $\cdot$ & $\cdot$ \\
\hline Likelihood test & $\begin{array}{l}\text { Period F } \\
\text { Prob. (0.0002), }\end{array}$ & $\begin{array}{l}\text { Period F } \\
\text { Prob. }(0.0000)\end{array}$ & $\begin{array}{l}\text { Period F } \\
\text { Prob. }(0.0000)\end{array}$ \\
\hline Random (period) & $\cdot$ & $\cdot$ & $\cdot$ \\
\hline Random (bank) & $\checkmark$ & $\checkmark$ & $\checkmark$ \\
\hline Hausman test & Prob. (0.0009) & Prob. (0.0000) & Prob. $(0.0000)$ \\
\hline Adjusted $R^{2}$ & 0.8718 & 0.6626 & 0.6791 \\
\hline
\end{tabular}

$*, * *$ and $* * *$ denote significance at $10 \%, 5 \%$ and $1 \%$ levels, respectively.

This table reports regression coefficients (standard deviations in parentheses) and diagnostic statistics for the performance regression in Equation 5. Three performance indicators are used as the dependent variable: $\log ($ profit), Tobin's Q and P/B. The sample comprises all banks. None of the three regressions pass the diagnostic checks. 
Table 5 Descriptive statistics of the key variables of executive pay dispersion

\begin{tabular}{|l|l|l|l|l|}
\hline & developing countries & developed countries & civil law countries & common law countries \\
\hline Sample banks number & 29 banks & 63 banks & 36 banks & 27 banks \\
\hline Mean & 0.2515 & 0.4673 & 0.4274 & 0.5016 \\
\hline Min & 0.0000 & 0.0000 & 0.0000 & 0.0083 \\
\hline Max & 1.0062 & 1.4593 & 1.4593 & 1.2391 \\
\hline Standard deviation & 0.2509 & 0.2723 & 0.2978 & 0.2439 \\
\hline
\end{tabular}


Table 6 Performance regression results - Developing country banks (29 banks(

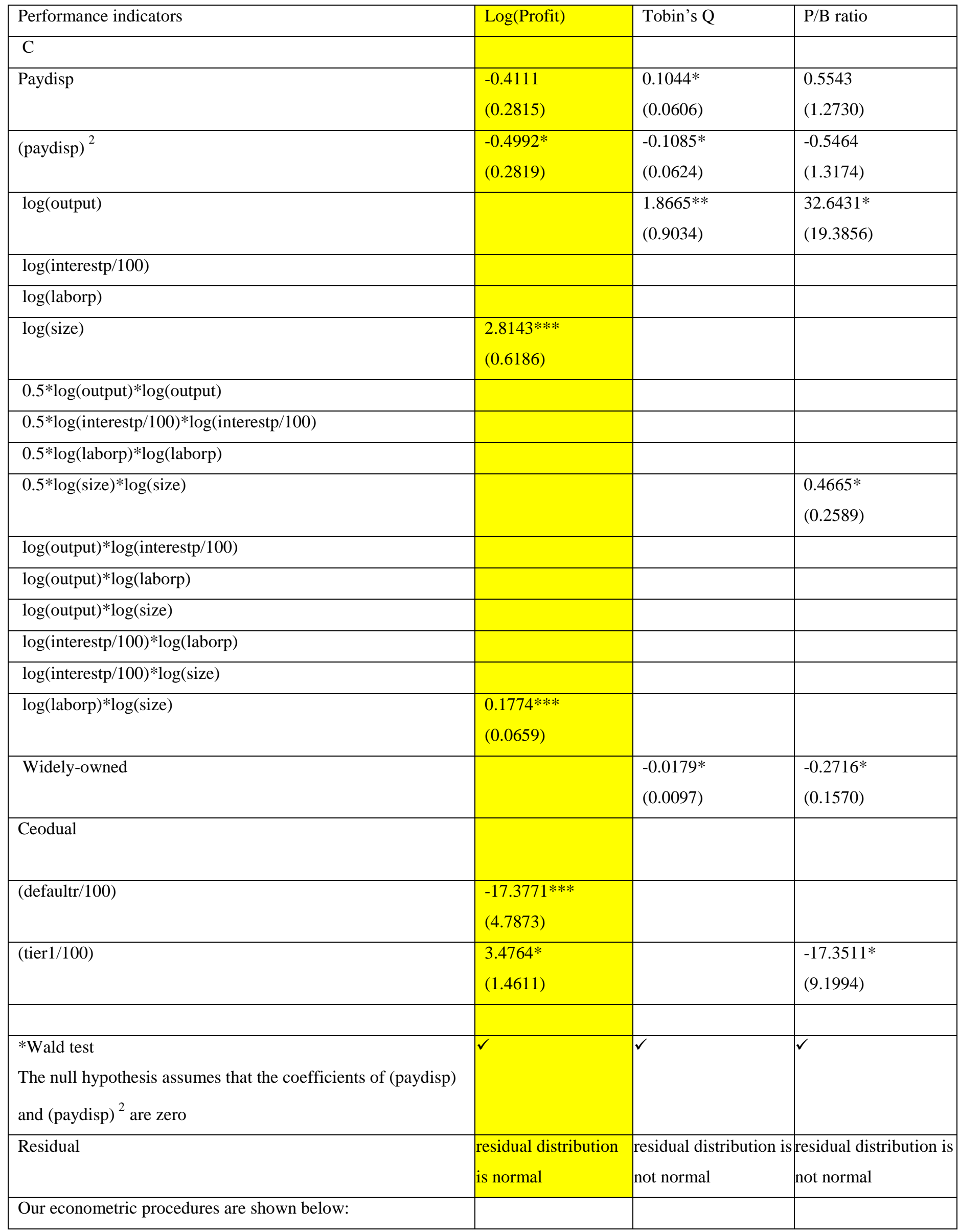




\begin{tabular}{|l|l|l|l|}
\hline Time fixed effect & $\checkmark$ & $\checkmark$ & $\checkmark$ \\
\hline Bank fixed effect & $\cdot$ & $\cdot$ & $\cdot$ \\
\hline Fixed (both) & $\cdot$ & $\cdot$ & $\cdot$ \\
\hline Likelihood test & $\begin{array}{l}\text { Period F } \\
\text { Prob. (0.0000) }\end{array}$ & $\begin{array}{l}\text { Period F } \\
\text { Prob. (0.0000) }\end{array}$ & $\begin{array}{l}\text { Period F } \\
\text { Prob. (0.0000) }\end{array}$ \\
\hline Random (period) & $\cdot$ & $\cdot$ & $\cdot$ \\
\hline Random (bank) & $\cdot$ & $\cdot$ & $\checkmark$ \\
\hline Hausman test & $\cdot$ & $\cdot$ & Prob. (0.0254), \\
\hline Adjusted $R^{2}$ & 0.9956 & 0.8268 & 0.8383 \\
\hline
\end{tabular}

$*, * *$ and $* * *$ denote significance at $10 \%, 5 \%$ and $1 \%$ levels, respectively.

This table reports regression coefficients (standard deviations in parentheses) and diagnostic statistics for the performance regression in Equation 5. Three performance indicators are used as the dependent variable: $\log ($ profit), Tobin's $\mathrm{Q}$ and $\mathrm{P} / \mathrm{B}$. The sample comprises developing country banks. The regression for $\log$ (profit) passes the diagnostic checks while the regression two regressions for Tobin's $\mathrm{Q}$ and $\mathrm{P} / \mathrm{B}$ do not. 
Table 7 Performance regression results- Developed country banks (63 banks)

\begin{tabular}{|c|c|c|c|}
\hline Performance indicators & $\log$ (Profit) & Tobin's Q & $\mathrm{P} / \mathrm{B}$ ratio \\
\hline $\mathrm{C}$ & $\begin{array}{l}-48.2512 * * * \\
(11.2501)\end{array}$ & & \\
\hline Paydisp & $\begin{array}{l}0.6176 \\
(0.9752)\end{array}$ & $\begin{array}{l}-0.0690 * * \\
(0.0290)\end{array}$ & $\begin{array}{l}-0.9698^{*} \\
(0.5291)\end{array}$ \\
\hline (paydisp) $^{2}$ & $\begin{array}{l}-0.0261 \\
(0.7727)\end{array}$ & $\begin{array}{l}0.0630 \text { *** } \\
(0.0213)\end{array}$ & $\begin{array}{l}0.8760 * * \\
(0.3821)\end{array}$ \\
\hline \multicolumn{4}{|l|}{$\log ($ output $)$} \\
\hline \multicolumn{4}{|l|}{$\log ($ interestp/100) } \\
\hline $\log ($ laborp) & $\begin{array}{l}-5.7785^{*} \\
(3.2828)\end{array}$ & & \\
\hline $\log ($ size $)$ & $\begin{array}{l}5.6797 * * * \\
(1.2764)\end{array}$ & & \\
\hline \multicolumn{4}{|l|}{$0.5 * \log ($ output $) * \log ($ output $)$} \\
\hline $0.5 * \log ($ interestp/100)* $\log ($ interestp/100) & $\begin{array}{l}1.0571 * * \\
(0.5174)\end{array}$ & & \\
\hline $0.5 * \log ($ laborp $) * \log ($ laborp $)$ & & & $\begin{array}{l}1.1717 * * \\
(0.5180)\end{array}$ \\
\hline $0.5 * \log ($ size $) * \log ($ size $)$ & $\begin{array}{l}-0.3030 * * \\
(0.1234)\end{array}$ & & $\begin{array}{l}-0.0929 * \\
(0.0555)\end{array}$ \\
\hline $\log ($ output $) * \log ($ interestp/100) & $\begin{array}{l}-0.9745^{*} \\
(0.5716)\end{array}$ & & \\
\hline \multicolumn{4}{|l|}{$\log ($ output $) * \log ($ laborp $)$} \\
\hline \multicolumn{4}{|l|}{$\log ($ output $) * \log ($ size $)$} \\
\hline $\log ($ interestp/100)*log(laborp) & & $\begin{array}{l}0.0329 * * \\
(0.0153)\end{array}$ & \\
\hline \multicolumn{4}{|l|}{$\log ($ interestp/100)* $\log ($ size $)$} \\
\hline \multicolumn{4}{|l|}{$\log (\text { laborp })^{*} \log ($ size $)$} \\
\hline Widely-owned & & $\begin{array}{l}0.0131 * * * \\
(0.0044)\end{array}$ & $\begin{array}{l}0.2149 * * * \\
(0.0760)\end{array}$ \\
\hline (defaultr/100) & $\begin{array}{l}-19.4252 * * * \\
(3.6797)\end{array}$ & $\begin{array}{l}-0.7318 * * * \\
(0.1899)\end{array}$ & $\begin{array}{l}-11.8308 * * * \\
(2.3645)\end{array}$ \\
\hline \multicolumn{4}{|l|}{$($ tier1/100) } \\
\hline $\begin{array}{l}\text { *Wald test } \\
\text { The null hypothesis assumes that the coefficients of (paydisp) and } \\
\text { (paydisp) }{ }^{2} \text { are zero }\end{array}$ & $\checkmark$ & $\checkmark$ & $\checkmark$ \\
\hline Residual & $\begin{array}{l}\text { residual not } \\
\text { normal }\end{array}$ & $\begin{array}{l}\text { residual } \\
\text { normal }\end{array}$ & $\begin{array}{l}\text { residual } \\
\text { normal }\end{array}$ \\
\hline
\end{tabular}




\begin{tabular}{|c|c|c|c|}
\hline Our econometric procedures are shown below: & & & \\
\hline Time fixed effect & $\checkmark$ & $\checkmark$ & $\checkmark$ \\
\hline Bank fixed effect & - & $\cdot$ & . \\
\hline Fixed (both) & - & . & $\cdot$ \\
\hline Likelihood test & $\begin{array}{l}\text { Period F } \\
\text { Prob. }(0.0002)\end{array}$ & $\begin{array}{l}\text { Period F } \\
\text { Prob. } \\
(0.0000)\end{array}$ & $\begin{array}{l}\text { Period F } \\
\text { Prob. }(0.0000)\end{array}$ \\
\hline Random (period) & $\cdot$ & $\cdot$ & $\cdot$ \\
\hline Random (bank; cross section random effects) & $\checkmark$ & $\checkmark$ & $\checkmark$ \\
\hline Hausman test & Prob. (0.1413) & $\begin{array}{l}\text { Prob. } \\
(0.0000)\end{array}$ & Prob. (0.0002) \\
\hline Adjusted $R^{2}$ & 0.7661 & 0.7998 & 0.7819 \\
\hline
\end{tabular}

*,** and *** denote significance at $10 \%, 5 \%$ and $1 \%$ levels, respectively.

This table reports regression coefficients (standard deviations in parentheses) and diagnostic statistics for the performance regression in Equation 5. Three performance indicators are used as the dependent variable: $\log$ (profit), Tobin's Q and P/B. The sample comprises 63 developed country banks. The two regressions for Tobin's $\mathrm{Q}$ and $\mathrm{P} / \mathrm{B}$ pass the diagnostic checks while the regression for profit does not. 
Table 8 Performance regression results- Common law country banks (27 banks)

\begin{tabular}{|c|c|c|c|}
\hline Performance indicators & Log(Profit) & Tobin's Q & $\mathrm{P} / \mathrm{B}$ ratio \\
\hline $\mathrm{C}$ & & $\begin{array}{l}3.3315 * \\
(1.6932)\end{array}$ & \\
\hline paydisp & $\begin{array}{l}-1.7485 \\
(1.9874)\end{array}$ & $\begin{array}{l}-0.0764 \\
(0.0612)\end{array}$ & $\begin{array}{l}0.0014 \\
(1.2696)\end{array}$ \\
\hline (paydisp) $^{2}$ & $\begin{array}{l}1.2763 \\
(1.7695)\end{array}$ & $\begin{array}{l}0.0590 \\
(0.0514)\end{array}$ & $\begin{array}{l}-0.0084 \\
(1.0590)\end{array}$ \\
\hline $\log ($ output $)$ & & $\begin{array}{l}2.0460 * * * \\
(0.7208)\end{array}$ & \\
\hline $\log ($ interestp/100) & & $\begin{array}{l}-2.0855 * * * \\
(0.5972)\end{array}$ & \\
\hline $\log ($ laborp) & & $\begin{array}{l}1.2089 * * \\
(0.4971)\end{array}$ & \\
\hline $\log ($ size $)$ & & & $\begin{array}{l}7.7824 * \\
(3.9412)\end{array}$ \\
\hline $0.5 * \log ($ output $) * \log ($ output $)$ & & $\begin{array}{l}-0.1728 * \\
(0.0950)\end{array}$ & \\
\hline $0.5^{*} \log ($ interestp $/ 100) * \log ($ inter & & & \\
\hline $0.5 * \log ($ laborp $) * \log ($ laborp $)$ & & & \\
\hline $0.5 * \log ($ size $) * \log ($ size $)$ & & & $\begin{array}{l}-0.5760 * * \\
(0.2810)\end{array}$ \\
\hline $\log ($ output $) * \log ($ interestp/100) & $\begin{array}{l}-4.0349 * * \\
(1.4851)\end{array}$ & & \\
\hline $\log ($ output $) * \log ($ laborp $)$ & & $\begin{array}{l}0.2421 * \\
(0.1249)\end{array}$ & \\
\hline $\log ($ output $) * \log ($ size $)$ & & $\begin{array}{l}-0.1276 * * * \\
(0.0384)\end{array}$ & \\
\hline $\log ($ interestp/100)*log(laborp) & & $\begin{array}{l}-0.1976 * * \\
(0.0778)\end{array}$ & \\
\hline $\log ($ interestp/100)* $\log ($ size $)$ & & $\begin{array}{l}0.1149 * * * \\
(0.0316)\end{array}$ & \\
\hline $\log (\text { laborp })^{*} \log ($ size $)$ & & $\begin{array}{l}-0.0684 * * \\
(0.0261)\end{array}$ & \\
\hline Widely-owned & & $\begin{array}{l}0.0425 * * * \\
(0.0116)\end{array}$ & \\
\hline (defaultr/100) & $\begin{array}{l}-62.5371 * * * \\
(11.7601)\end{array}$ & $\begin{array}{l}-0.4459 * * * \\
(0.0798)\end{array}$ & $\begin{array}{l}-9.9962 * * * \\
(1.7676)\end{array}$ \\
\hline \multicolumn{4}{|l|}{ (tier1/100) } \\
\hline *Wald test & $\checkmark$ & $\checkmark$ & $\checkmark$ \\
\hline
\end{tabular}




\begin{tabular}{|c|c|c|c|}
\hline $\begin{array}{l}\text { The null hypothesis assumes that the coefficients of (paydisp) and } \\
\text { (paydisp) }{ }^{2} \text { are zero }\end{array}$ & & & \\
\hline Residual & $\begin{array}{l}\text { residual } \\
\text { normal }\end{array}$ & $\begin{array}{l}\text { residual } \\
\text { normal }\end{array}$ & $\begin{array}{l}\text { residual } \\
\text { normal }\end{array}$ \\
\hline \multicolumn{4}{|l|}{ Our econometric procedures are shown below: } \\
\hline Time fixed effect & $\checkmark$ & $\checkmark$ & $\checkmark$ \\
\hline Bank fixed effect & $\cdot$ & $\cdot$ & $\cdot$ \\
\hline Fixed (both) & $\cdot$ & $\cdot$ & $\cdot$ \\
\hline Likelihood test & $\begin{array}{l}\text { Period F } \\
\text { Prob. (0.1157) }\end{array}$ & $\begin{array}{l}\text { Period F } \\
\text { Prob. }(0.0000)\end{array}$ & $\begin{array}{l}\text { Period F } \\
\text { Prob. }(0.0000)\end{array}$ \\
\hline Random (period) & $\cdot$ & $\cdot$ & $\cdot$ \\
\hline Random (bank) & $\cdot$ & $\cdot$ & $\cdot$ \\
\hline Hausman test & $\cdot$ & $\cdot$ & $\cdot$ \\
\hline Adjusted $R^{2}$ & 0.8566 & 0.8587 & 0.8279 \\
\hline
\end{tabular}

$*, * *$ and $* * *$ denote significance at $10 \%, 5 \%$ and $1 \%$ levels, respectively.

This table reports regression coefficients (standard deviations in parentheses) and diagnostic statistics for the performance regression in Equation 5. Three performance indicators are used as the dependent variable: $\log ($ profit), Tobin's Q and P/B. The sample comprises 27 common law country banks. None of the three regressions pass the diagnostic checks. 
Table 9 Performance regression results - Civil law country banks (36 banks)

\begin{tabular}{|c|c|c|c|}
\hline Performance indicators & Log(Profit) & Tobin's Q & $\mathrm{P} / \mathrm{B}$ ratio \\
\hline $\mathrm{C}$ & $\begin{array}{l}-36.5269 * * \\
(15.5112)\end{array}$ & $\begin{array}{l}0.8903 * \\
(0.5268)\end{array}$ & \\
\hline paydisp & $\begin{array}{l}0.7663 \\
(1.2490)\end{array}$ & $\begin{array}{l}-0.0851 * * * \\
(0.0194)\end{array}$ & $\begin{array}{l}-1.8034 \text { *** } \\
(0.5147)\end{array}$ \\
\hline (paydisp) $^{2}$ & $\begin{array}{l}-0.5456 \\
(0.8979)\end{array}$ & $\begin{array}{l}0.0652 * * * \\
(0.0143)\end{array}$ & $\begin{array}{l}1.2663 * * * \\
(0.4068)\end{array}$ \\
\hline \multicolumn{4}{|l|}{$\log ($ output $)$} \\
\hline \multicolumn{4}{|l|}{$\log ($ interestp/100) } \\
\hline \multicolumn{4}{|l|}{$\log ($ laborp $)$} \\
\hline $\log ($ size $)$ & $\begin{array}{l}4.5645 * * \\
(1.7920)\end{array}$ & & \\
\hline $0.5 * \log ($ output $) * \log ($ output $)$ & & $\begin{array}{l}0.1136 * * \\
(0.0439)\end{array}$ & $\begin{array}{l}2.5187 * \\
(1.2754)\end{array}$ \\
\hline $0.5 * \log ($ interestp/100)* $\log ($ interestp/100) & $\begin{array}{l}2.0830 * \\
(1.1705)\end{array}$ & $\begin{array}{l}0.0413 * * \\
(0.0195)\end{array}$ & \\
\hline $0.5 * \log ($ laborp $) * \log ($ laborp $)$ & & $\begin{array}{l}0.0356^{*} \\
(0.0203)\end{array}$ & $\begin{array}{l}1.6115 * * * \\
(0.4644)\end{array}$ \\
\hline \multicolumn{4}{|l|}{$0.5 * \log ($ size $) * \log ($ size $)$} \\
\hline $\log ($ output $) * \log ($ interestp/100) & $\begin{array}{l}-2.5777 * \\
(1.4617)\end{array}$ & $\begin{array}{l}-0.0714 * * \\
(0.0274)\end{array}$ & \\
\hline \multicolumn{4}{|l|}{$\log ($ output $) * \log ($ laborp $)$} \\
\hline $\log ($ output $) * \log ($ size $)$ & $\begin{array}{l}0.5928^{*} \\
(0.3024)\end{array}$ & & \\
\hline \multicolumn{4}{|l|}{$\log ($ interestp/100)*log(laborp) } \\
\hline $\log ($ interestp/100)* $\log ($ size $)$ & & $\begin{array}{l}-0.0097 * * * \\
(0.0032)\end{array}$ & \\
\hline $\log (\text { laborp })^{*} \log ($ size $)$ & & $\begin{array}{l}0.0205 * * \\
(0.0090)\end{array}$ & \\
\hline Widely-owned & & $\begin{array}{l}0.0070 * \\
(0.0042)\end{array}$ & $\begin{array}{l}0.1276 * \\
(0.0735)\end{array}$ \\
\hline (defaultr/100) & $\begin{array}{l}-14.5276 * * * \\
(4.8367)\end{array}$ & $\begin{array}{l}-0.6735 * * * \\
(0.1998)\end{array}$ & $\begin{array}{l}-6.9496 * \\
(3.7985)\end{array}$ \\
\hline (tier1/100) & $\begin{array}{l}-11.9637 * * \\
(5.9460)\end{array}$ & $\begin{array}{l}0.3263^{* * * *} \\
(0.1009)\end{array}$ & \\
\hline *Wald test & $\checkmark$ & $\checkmark$ & $\checkmark$ \\
\hline
\end{tabular}




\begin{tabular}{|l|l|l|l|l|}
\hline $\begin{array}{l}\text { The null hypothesis assumes that the coefficients of (paydisp) and } \\
\text { (paydisp) }{ }^{2} \text { are zero }\end{array}$ & \multicolumn{2}{|l|}{} & \\
\hline Rsidual & \multicolumn{2}{|l|}{$\begin{array}{l}\text { residual not } \\
\text { normal }\end{array}$} & $\begin{array}{l}\text { residual } \\
\text { normal }\end{array}$ & residual normal \\
\hline Our econometric procedures are shown below: & $\checkmark$ & $\checkmark$ & $\checkmark$ \\
\hline Time fixed effect & $\cdot$ & $\cdot$ & $\cdot$ \\
\hline Bank fixed effect & $\cdot$ & $\cdot$ & $\cdot$ \\
\hline Fixed (both) & $\begin{array}{l}\text { Period F } \\
\text { Likelihood test }\end{array}$ & Prob. (0.0004) & $\begin{array}{l}\text { Prob. } \\
\text { Prob. F } \\
\text { (0.0000) }\end{array}$ & $\begin{array}{l}\text { Period F } \\
\text { Prob. (0.0000) }\end{array}$ \\
\hline Random (period) & $\cdot$ & $\cdot$ & $\cdot$ \\
\hline Random (bank) & $\checkmark$ & $\checkmark$ & $\checkmark$ \\
\hline Hausman test & Prob. (0.7082) & Prob. (0.0001) & Prob. (0.0000) \\
\hline Adjusted $R^{2}$ & 0.7108 & 0.9045 & 0.8535 \\
\hline
\end{tabular}

$*, * *$ and $* * *$ denote significance at $10 \%, 5 \%$ and $1 \%$ levels, respectively.

This table reports regression coefficients (standard deviations in parentheses) and diagnostic statistics for the performance regression in Equation 5. Three performance indicators are used as the dependent variable: $\log ($ profit), Tobin's Q and P/B. The sample comprises 36 civil law country banks. The two regressions for Tobin's $\mathrm{Q}$ and $\mathrm{P} / \mathrm{B}$ pass the diagnostic checks while the regression for profit does not. 
Table 10 Performance regression robustness check - Common law country banks (27 banks)

\begin{tabular}{|c|c|c|c|}
\hline & $\begin{array}{c}\text { (1) Original } \\
\text { (time-fixed effect model) }\end{array}$ & $\begin{array}{l}\text { (2) New } \\
\text { (with VIX index; } \\
\text { without the time-fixed } \\
\text { effect model) }\end{array}$ & \begin{tabular}{l}
\multicolumn{1}{c}{ (3) New } \\
(with a time \\
dummy; \\
without the time- \\
fixed effect model)
\end{tabular} \\
\hline Performance indicator & Tobin's Q & Tobin's Q & Tobin's Q \\
\hline $\mathrm{C}$ & $\begin{array}{l}3.3315^{*} \\
(1.6932)\end{array}$ & & \\
\hline Paydisp & $\begin{array}{l}-0.0764 \\
(0.0612)\end{array}$ & $\begin{array}{l}-0.0864 \\
(0.0603)\end{array}$ & $\begin{array}{l}-0.0838 \\
(0.0813)\end{array}$ \\
\hline (paydisp) $^{2}$ & $\begin{array}{l}0.0590 \\
(0.0514)\end{array}$ & $\begin{array}{l}0.0657 \\
(0.0478)\end{array}$ & $\begin{array}{l}0.0804 \\
(0.0682)\end{array}$ \\
\hline $\log ($ output $)$ & $\begin{array}{l}2.0460 * * * \\
(0.7208)\end{array}$ & $\begin{array}{l}2.0225^{* *} \\
(0.7482)\end{array}$ & $\begin{array}{l}1.6808 * * \\
(0.7516)\end{array}$ \\
\hline $\log ($ interestp/100) & $\begin{array}{l}-2.0855 * * * \\
(0.5972)\end{array}$ & $\begin{array}{l}-2.0673 * * * \\
(0.5523)\end{array}$ & $\begin{array}{l}-1.9539 * * * \\
(0.5520)\end{array}$ \\
\hline $\log$ (laborp) & $\begin{array}{l}1.2089 * * \\
(0.4971)\end{array}$ & $\begin{array}{l}0.9347^{*} \\
(0.5235)\end{array}$ & \\
\hline $\log ($ size $)$ & & & \\
\hline $0.5 * \log ($ output $) * \log ($ output $)$ & $\begin{array}{l}-0.1728 * \\
(0.0950)\end{array}$ & & \\
\hline $\begin{array}{l}0.5 * \log (\text { interestp } / 100) * \log (\text { interest } \\
\mathrm{p} / 100)\end{array}$ & & & \\
\hline $0.5 * \log ($ laborp $) * \log ($ laborp $)$ & & & \\
\hline $0.5 * \log ($ size $) * \log ($ size $)$ & & & \\
\hline $\log ($ output $) * \log ($ interestp/100) & & & $\begin{array}{l}0.0703 * \\
(0.0412)\end{array}$ \\
\hline $\log ($ output $) * \log ($ laborp $)$ & $\begin{array}{l}0.2421 * \\
(0.1249)\end{array}$ & $\begin{array}{l}0.2396 * \\
(0.1299)\end{array}$ & \\
\hline $\log ($ output $) * \log ($ size $)$ & $\begin{array}{l}-0.1276 * * * \\
(0.0384)\end{array}$ & $\begin{array}{l}-0.1231 * * * \\
(0.0399)\end{array}$ & $\begin{array}{l}-0.1165^{* *} \\
(0.0428)\end{array}$ \\
\hline $\log ($ interestp/100)*log(laborp) & $\begin{array}{l}-0.1976 * * \\
(0.0778)\end{array}$ & $\begin{array}{l}-0.1877 * * \\
(0.0753)\end{array}$ & $\begin{array}{l}-0.1915 * * \\
(0.0756)\end{array}$ \\
\hline
\end{tabular}




\begin{tabular}{|c|c|c|c|}
\hline $\log ($ interestp/100)*log $($ size $)$ & $\begin{array}{l}0.1149 * * * \\
(0.0316)\end{array}$ & $\begin{array}{l}0.1127 * * * \\
(0.0295)\end{array}$ & $\begin{array}{l}0.1244 * * * \\
(0.0330)\end{array}$ \\
\hline $\log (\text { laborp })^{*} \log ($ size $)$ & $\begin{array}{l}-0.0684 * * \\
(0.0261)\end{array}$ & $\begin{array}{l}-0.0477 * \\
(0.0249)\end{array}$ & \\
\hline Widely-owned & $\begin{array}{l}0.0425 * * * \\
(0.0116)\end{array}$ & $\begin{array}{l}0.0436 * * * \\
(0.0116)\end{array}$ & $\begin{array}{l}0.0369 * * \\
(0.0172)\end{array}$ \\
\hline (defaultr/100) & $\begin{array}{l}-0.4459 * * * \\
(0.0798)\end{array}$ & $\begin{array}{l}-0.4322 * * * \\
(0.0843)\end{array}$ & $\begin{array}{l}-0.4305 * * * \\
(0.0886)\end{array}$ \\
\hline (tier1/100) & & & \\
\hline VIX Index & & $\begin{array}{l}-0.0031 * * * \\
(0.0004)\end{array}$ & \\
\hline Time Dummy & & & $\begin{array}{l}-0.0090 * * * \\
(0.0030)\end{array}$ \\
\hline Residual & residual normal & residual NOT normal & residual normal \\
\hline Time-fixed effect model & $\checkmark$ & & \\
\hline Adjusted $R^{2}$ & 0.8587 & 0.8481 & 0.7912 \\
\hline
\end{tabular}

$*, * *$ and $* * *$ denote significance at $10 \%, 5 \%$ and $1 \%$ levels, respectively.

This table reports regression coefficients (standard deviations in parentheses) and diagnostic statistics for the performance regression in Equation 5, using Tobin's Q as the performance indicator. The sample comprises 27 common law country banks. As a robustness check, three regressions are estimated: (1) original, (2) with VIX index and (3) with time dummy. The specification with the VIX index does not pass all diagnostic tests. 
Table 11 Performance regression robustness check (with/without VIX) - Developing country banks (23 banks)

\begin{tabular}{|c|c|c|c|c|c|c|}
\hline \multirow[t]{2}{*}{ Performance indicators } & \multicolumn{2}{|l|}{$\log$ (Profit) } & \multicolumn{2}{|l|}{ Tobin's Q } & \multicolumn{2}{|l|}{$\mathrm{P} / \mathrm{B}$ ratio } \\
\hline & $\begin{array}{l}\text { Without } \\
\text { VIX }\end{array}$ & With VIX & $\begin{array}{l}\text { Without } \\
\text { VIX }\end{array}$ & With VIX & $\begin{array}{l}\text { Without } \\
\text { VIX }\end{array}$ & With VIX \\
\hline $\mathrm{C}$ & & & & $\begin{array}{l}4.6700 * * \\
(1.9675)\end{array}$ & & $\begin{array}{l}90.7806 * * \\
(42.9405)\end{array}$ \\
\hline Paydisp & $\begin{array}{l}-0.4111 \\
(0.2815)\end{array}$ & $\begin{array}{l}0.1539 \\
(0.2563)\end{array}$ & $\begin{array}{l}0.1044 * \\
(0.0606)\end{array}$ & $\begin{array}{l}0.0007 \\
(0.0567)\end{array}$ & $\begin{array}{l}0.5543 \\
(1.2730)\end{array}$ & $\begin{array}{l}-0.3412 \\
(1.1401)\end{array}$ \\
\hline (paydisp) $^{2}$ & $\begin{array}{l}-0.4992 * \\
(0.2819)\end{array}$ & $\begin{array}{l}-0.2578 \\
(0.2508)\end{array}$ & $\begin{array}{l}-0.1085^{*} \\
(0.0624)\end{array}$ & $\begin{array}{l}-0.0161 \\
(0.0583)\end{array}$ & $\begin{array}{l}-0.5464 \\
(1.3174)\end{array}$ & $\begin{array}{l}0.2206 \\
(1.1867)\end{array}$ \\
\hline $\log ($ output $)$ & & & $\begin{array}{l}1.8665 * * \\
(0.9034)\end{array}$ & $\begin{array}{l}3.0195 * * \\
(1.1444)\end{array}$ & $\begin{array}{l}32.6431 * \\
(19.3856)\end{array}$ & $\begin{array}{l}60.0815 * * * \\
(22.4014)\end{array}$ \\
\hline $\log ($ interestp/100) & & & & $\begin{array}{l}-2.8624 * * \\
(1.2267)\end{array}$ & & $\begin{array}{l}-57.4884 * * \\
(24.5048)\end{array}$ \\
\hline $\log$ (laborp) & & & & $\begin{array}{l}1.0148 * * \\
(0.4194)\end{array}$ & & $\begin{array}{l}22.8334 * * \\
(9.3044)\end{array}$ \\
\hline $\log ($ size $)$ & $\begin{array}{l}2.8143 * * * \\
(0.6186)\end{array}$ & $\begin{array}{l}2.0506 * * * \\
(0.6956)\end{array}$ & & $\begin{array}{l}-0.3491^{*} \\
(0.2040)\end{array}$ & & $\begin{array}{l}-8.7674 * \\
(4.7276)\end{array}$ \\
\hline \multicolumn{7}{|l|}{$0.5 * \log ($ output $) * \log ($ output $)$} \\
\hline $0.5 * \log ($ interestp $/ 100) * \log ($ inter & & & & & & \\
\hline $0.5 * \log ($ laborp $) * \log ($ laborp $)$ & & & & $\begin{array}{l}0.0814 * \\
(0.0469)\end{array}$ & & $\begin{array}{l}1.7467 * \\
(0.9483)\end{array}$ \\
\hline $0.5 * \log ($ size $) * \log ($ size $)$ & & & & $\begin{array}{l}0.0258 * * \\
(0.0110)\end{array}$ & $\begin{array}{l}0.4665^{*} \\
(0.2589)\end{array}$ & $\begin{array}{l}0.5872 * * \\
(0.2302)\end{array}$ \\
\hline \multicolumn{7}{|l|}{$\log ($ output $) * \log ($ interestp/100) } \\
\hline $\log ($ output $) * \log ($ laborp $)$ & & & & $\begin{array}{l}0.3372 * * \\
(0.1456)\end{array}$ & & $\begin{array}{l}6.7019 * * \\
(2.7448)\end{array}$ \\
\hline $\log ($ output $) * \log ($ size $)$ & & & & & & $\begin{array}{l}-1.6591 * \\
(0.8726)\end{array}$ \\
\hline $\log ($ interestp/100)*log(laborp) & & & & $\begin{array}{l}-0.2710^{*} \\
(0.1481)\end{array}$ & & $\begin{array}{l}-5.3153^{*} \\
(2.7893)\end{array}$ \\
\hline $\log ($ interestp/100)* $\log ($ size $)$ & & & & $\begin{array}{l}0.1082 * * * \\
(0.0355)\end{array}$ & & $\begin{array}{l}2.5137 * * * \\
(0.7381)\end{array}$ \\
\hline $\log (\text { laborp })^{*} \log ($ size $)$ & $\begin{array}{l}0.1774 * * * \\
(0.0659)\end{array}$ & & & $\begin{array}{l}-0.0539 * * \\
(0.0263)\end{array}$ & & $\begin{array}{l}-1.2148 * * \\
(0.5682)\end{array}$ \\
\hline Widely-owned & & & $\begin{array}{l}-0.0179^{*} \\
(0.0097)\end{array}$ & & $\begin{array}{l}-0.2716^{*} \\
(0.1570)\end{array}$ & \\
\hline Ceodual & & & & & & \\
\hline (defaultr/100) & $\begin{array}{l}- \\
17.3771 * * * \\
(4.7873)\end{array}$ & & & & & \\
\hline
\end{tabular}




\begin{tabular}{|l|l|l|l|l|l|l|}
\hline (tier1/100) & $\begin{array}{l}3.4764^{*} \\
(1.4611)\end{array}$ & $\begin{array}{l}3.7412^{* * *} \\
(1.2257)\end{array}$ & & & $\begin{array}{l}-17.3511^{*} \\
(9.1994)\end{array}$ & $\begin{array}{l}-15.6873^{* *} \\
(7.1180)\end{array}$ \\
\hline VIX index & & $\begin{array}{l}2.23 \mathrm{E}-05 \\
(0.0036)\end{array}$ & & $\begin{array}{l}-0.0019 \\
(0.0016)\end{array}$ & $\begin{array}{l}-0.0276 \\
(0.0326)\end{array}$ \\
\hline Residual & $\begin{array}{l}\text { residual } \\
\text { distribution } \\
\text { is normal } \\
\text { distribution } \\
\text { is normal }\end{array}$ & $\begin{array}{l}\text { residual } \\
\text { distribution } \\
\text { is not } \\
\text { normal }\end{array}$ & $\begin{array}{l}\text { residual } \\
\text { distribution } \\
\text { is not } \\
\text { normal }\end{array}$ \\
Time fixed effect & $\checkmark$ & $\begin{array}{l}\text { residual } \\
\text { distribution } \\
\text { is not } \\
\text { normal }\end{array}$ & $\begin{array}{l}\text { residual } \\
\text { is not } \\
\text { normal }\end{array}$ \\
\hline Adjusted $R^{2}$ & 0.9956 & 0.9939 & 0.8268 & 0.4697 & 0.8383 & 0.4689 \\
\hline
\end{tabular}

$*, * *$ and $* * *$ denote significance at $10 \%, 5 \%$ and $1 \%$ levels, respectively.

This table reports regression coefficients (standard deviations in parentheses) and diagnostic statistics for the performance regression in Equation 5. Three performance indicators are used as the dependent variable: $\log ($ profit), Tobin's $\mathrm{Q}$ and $\mathrm{P} / \mathrm{B}$. The sample comprises 23 developing country banks. As a robustness check, two regressions are estimated per performance indicator: (1) original and (2) with VIX index. 
Table 12 Summary of empirical results - pay dispersion variable

\begin{tabular}{|c|c|c|c|}
\hline Performance indicators & $\log$ (Profit) & Tobin's Q & $\mathrm{P} / \mathrm{B}$ \\
\hline $\begin{array}{l}\text { developing countries } \\
\text { ( } 29 \text { banks) }\end{array}$ & Equity fairness theory & Neither* & Neither* \\
\hline $\begin{array}{l}\text { developed countries } \\
\text { (63 banks) }\end{array}$ & Neither* & $\begin{array}{l}\text { Equity fairness; except for } \\
\text { very high pay dispersion (U- } \\
\text { shaped impact curve) }\end{array}$ & $\begin{array}{l}\text { Equity fairness; except for very } \\
\text { high pay dispersion (U-shaped } \\
\text { impact curve) }\end{array}$ \\
\hline $\begin{array}{l}\text { civil law } \\
\text { (36 banks) }\end{array}$ & Neither* & $\begin{array}{l}\text { Equity fairness; except for } \\
\text { very high pay dispersion (U- } \\
\text { shaped impact curve) }\end{array}$ & $\begin{array}{l}\text { Equity fairness; except for very } \\
\text { high pay dispersion (U-shaped } \\
\text { impact curve) }\end{array}$ \\
\hline $\begin{array}{l}\text { common law } \\
\text { ( } 27 \text { banks) }\end{array}$ & Neither & Neither & Neither \\
\hline
\end{tabular}

* Residuals of regression non-normal 


\section{Figures}

Fig. 1 - Developing countries $-\log ($ Profit $)$

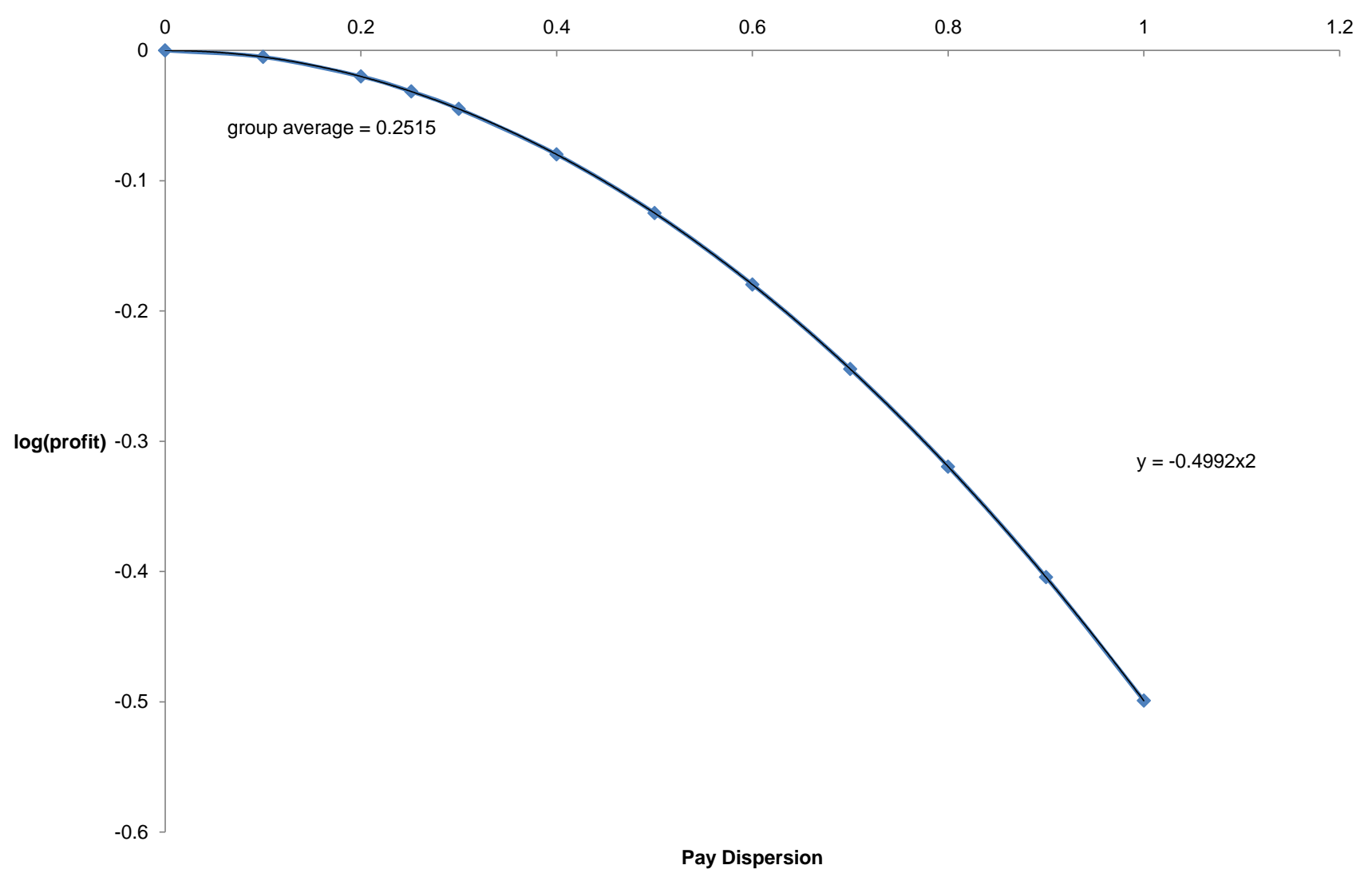

This Figures shows the relationship between the $\log$ (profit) performance indicator and the linear and quadratic executive pay dispersion variables if the latter are statistically significant in the performance regression in Equation 5. The sample group comprises banks in developing countries. The group average for pay dispersion is also reported on the Figure. 
Fig. 2 - Developed countries- Tobin's Q

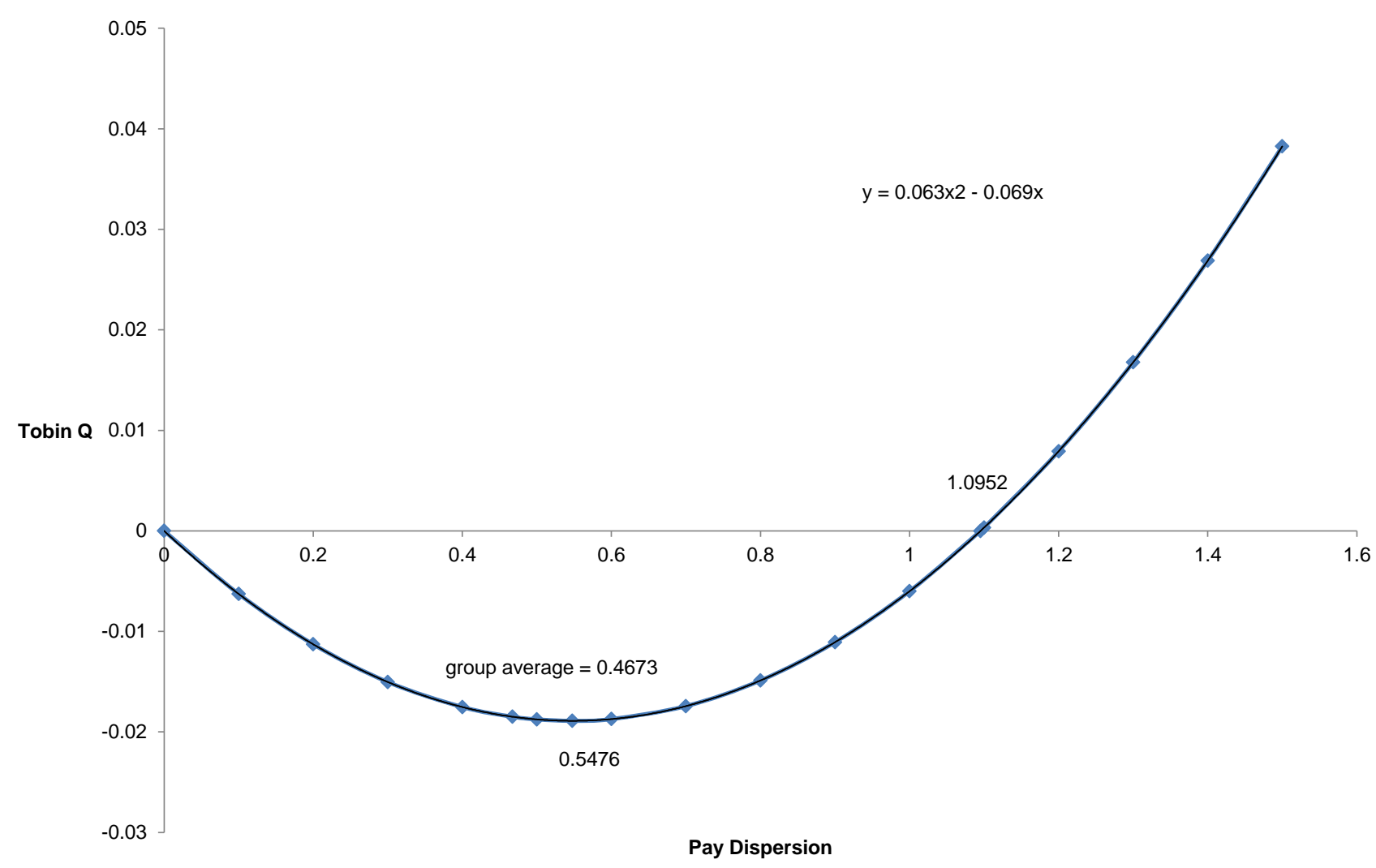

This Figure shows the relationship between Tobin's $Q$ and the linear and quadratic executive pay dispersion variables if the latter are statistically significant in the performance regression in Equation 5. The sample group comprises banks in developed countries. The group average for pay dispersion is also reported on the Figure. 
Fig. 3 - Developed countries - P/B ratio

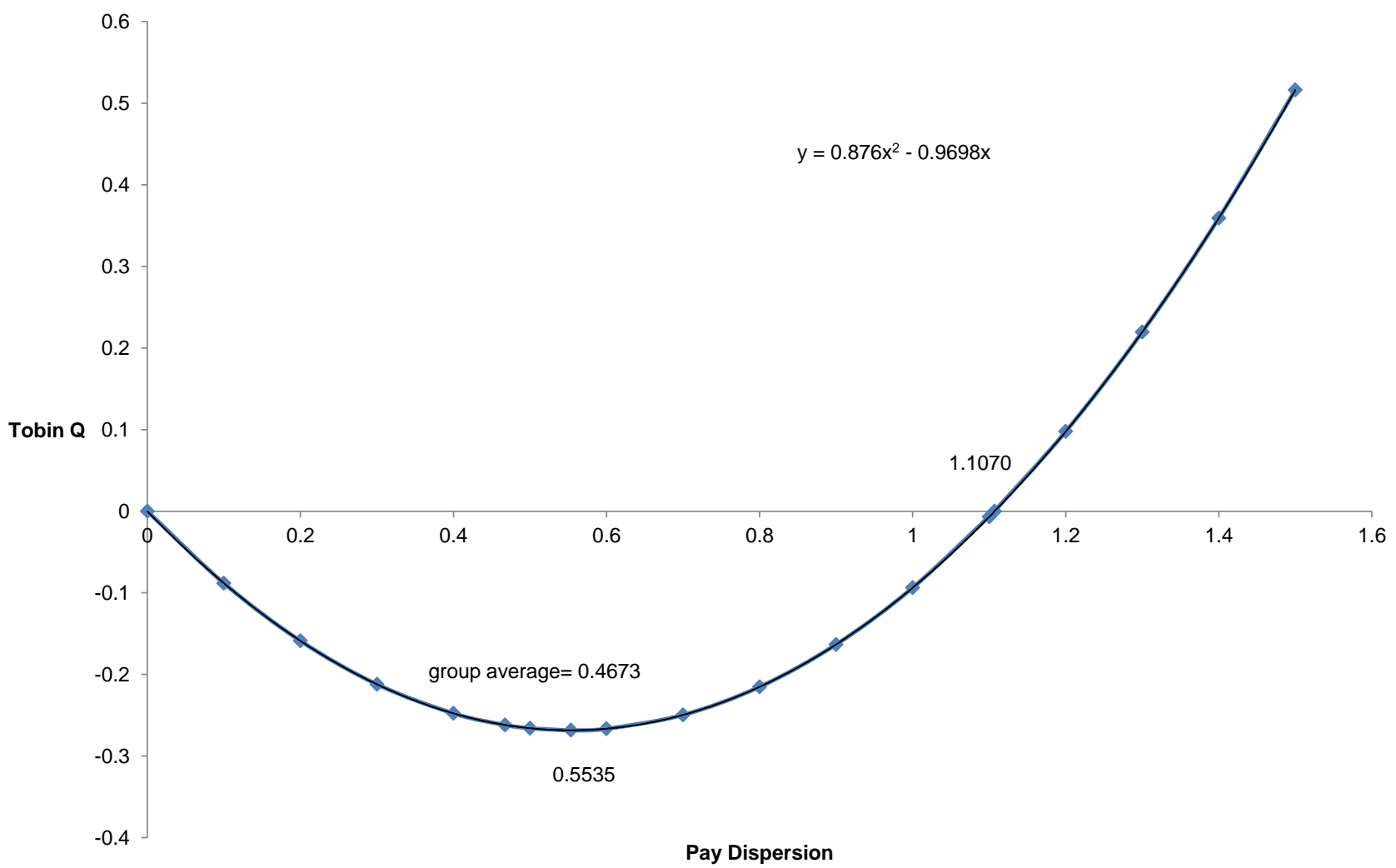

This Figure shows the relationship between P/B and the linear and quadratic executive pay dispersion variables if the latter are statistically significant in the performance regression in Equation 5. The sample group comprises banks in developed countries. The group average value for pay dispersion is also reported on the Figure. 
Fig. 4 - Civil law countries- Tobin's $Q$

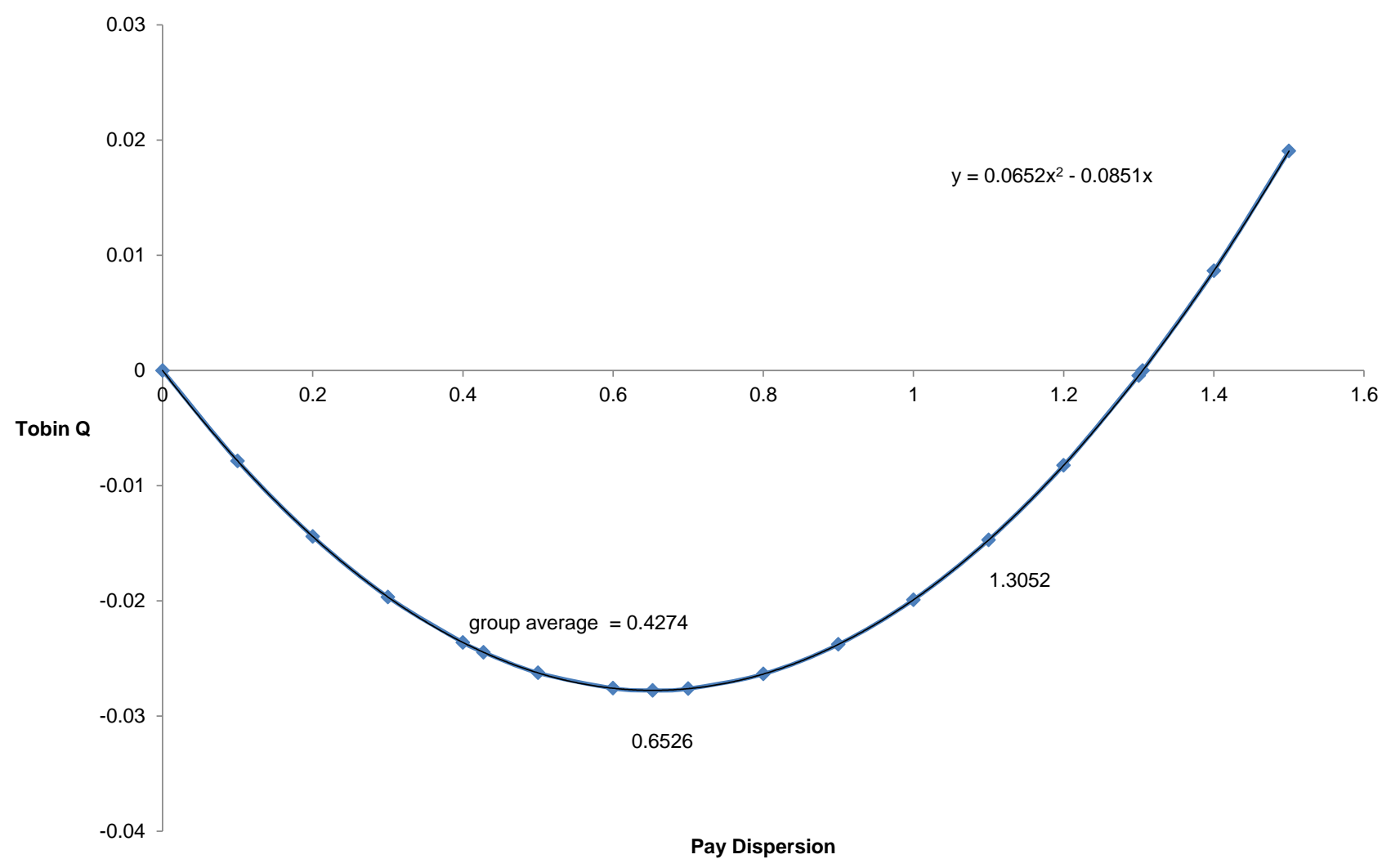

This Figure shows the relationship between Tobin's $Q$ and the linear and quadratic executive pay dispersion variables if the latter are statistically significant in the performance regression in Equation 5. The sample group comprises banks in civil law countries. The group average for pay dispersion is also reported on the Figure. 
Fig. 5 - Civil law countries - P/B ratio

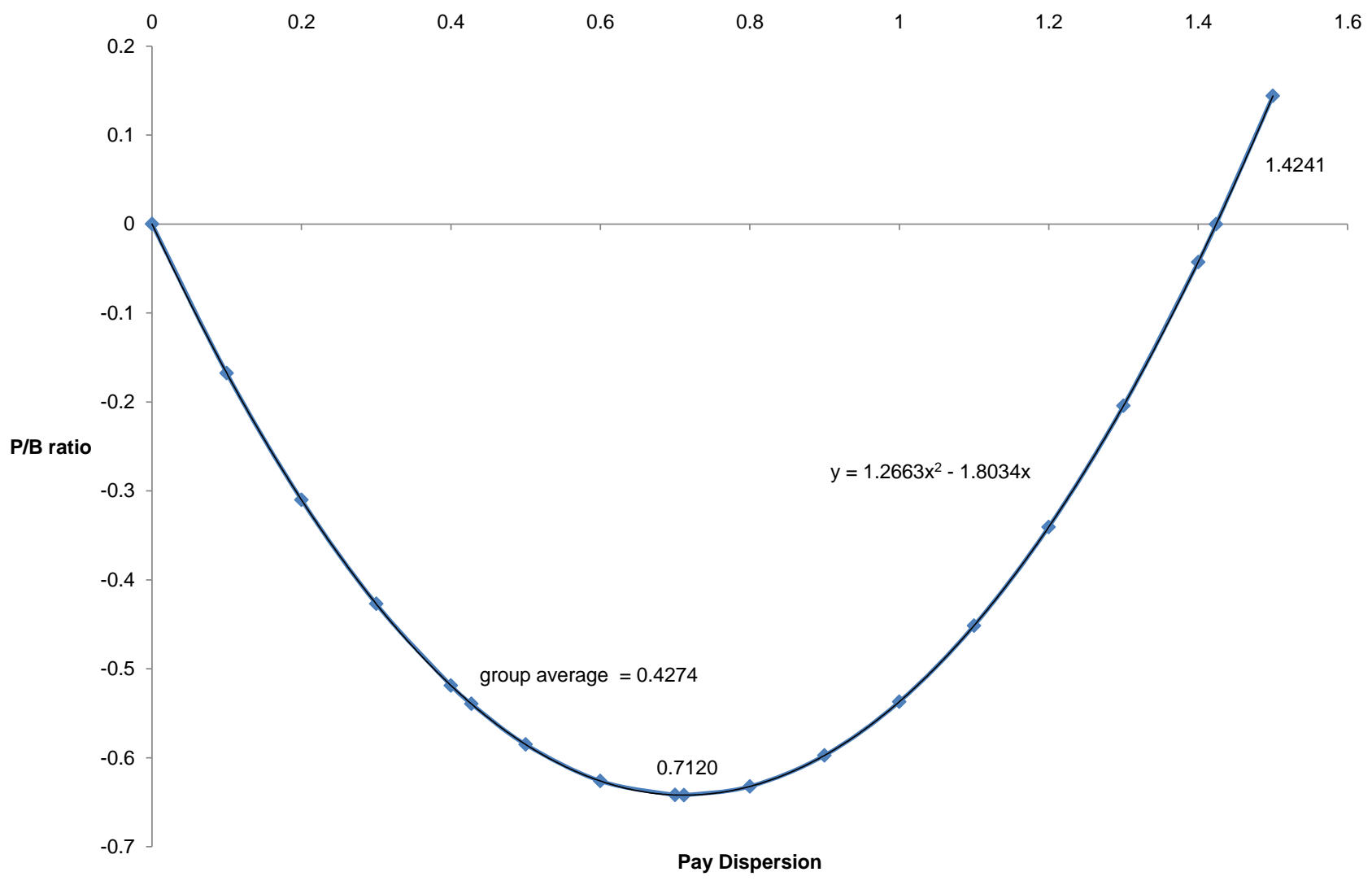

This Figure shows the relationship between the P/B ratio and the linear and quadratic executive pay dispersion variables if the latter are statistically significant in the performance regression in Equation 5. The sample group comprises banks in civil law countries. The group average for pay dispersion is also reported on the Figure. 


\section{Appendix A.}

Table 13 List of sample banks - 92 banks worldwide

\begin{tabular}{|c|c|}
\hline Country & Bank \\
\hline \multirow[t]{2}{*}{ Belgium } & Dexia \\
\hline & KBC Group-KBC Groep NV/KBC Groupe SA \\
\hline \multirow[t]{2}{*}{ Ireland } & Allied Irish Banks plc \\
\hline & Bank of Ireland \\
\hline \multirow[t]{8}{*}{ USA } & Citigroup Inc \\
\hline & Fannie Mae-Federal National Mortgage Association \\
\hline & Goldman Sachs Group Inc \\
\hline & JP Morgan Chase \& Co. \\
\hline & Merrill Lynch \& Co., Inc. \\
\hline & Metlife, Inc. \\
\hline & Morgan Stanley \\
\hline & Wells Fargo \& Company \\
\hline \multirow[t]{5}{*}{ Spain } & Banco Bilbao Vizcaya Argenaria SA \\
\hline & Banco de Sabadell SA \\
\hline & Banco Santander SA \\
\hline & Bankinter SA \\
\hline & Caja de Ahorros del Mediterraneo CAM \\
\hline Portugal & Banco BPI SA \\
\hline \multirow[t]{3}{*}{ Netherlands } & Bank Nederlandse Gemeenten NV, BNG \\
\hline & ING Groep Nv \\
\hline & SNS Reaal NV \\
\hline \multirow[t]{4}{*}{ Australia } & Bank of Western Australia Limited \\
\hline & Commonwealth Bank of Australia \\
\hline & Macquarie Group Ltd \\
\hline & National Australia Bank Limited \\
\hline Switzerland & Credit Suisse Group AG \\
\hline Denmark & Danske Bank A/S \\
\hline Norway & DnB Nor ASA \\
\hline \multirow[t]{2}{*}{ Austria } & Erste Group Bank AG \\
\hline & Raiffeisen Bank International AG \\
\hline \multirow[t]{5}{*}{ UK } & Barclays Plc \\
\hline & HSBC Holdings Plc \\
\hline & Lloyds Banking Group Plc \\
\hline & Royal Bank of Scotland Group Plc (The) \\
\hline & Standard Chartered Plc \\
\hline
\end{tabular}




\begin{tabular}{|c|c|}
\hline Sweden & Swedbank AB \\
\hline Finland & OP-Pohjola Group \\
\hline \multirow[t]{9}{*}{ Italy } & Banca Carige SpA \\
\hline & Banca Popolare dell'Emilia Romagna \\
\hline & Banca Popolare di Milano ScaRL \\
\hline & Banca Popolare di Sondrio \\
\hline & Credito Emiliano SpA \\
\hline & Intesa Sanpaolo \\
\hline & Mediobanca SpA \\
\hline & UBI Banca \\
\hline & UniCredit SpA \\
\hline \multirow[t]{8}{*}{ Canada } & Bank of Nova Scotia (The) -Scotiabank \\
\hline & Banque Nationale du Canada-National Bank of Canada \\
\hline & Canadian Imperial Bank of Commerce CIBC \\
\hline & Laurentian Bank of Canada \\
\hline & Manulife Bank of Canade \\
\hline & Royal Bank of Canada RBC \\
\hline & Toronto Dominion Bank \\
\hline & Bank of Montreal \\
\hline \multirow[t]{4}{*}{ Germany } & Commerzbank AG \\
\hline & Deutsche Bank AG \\
\hline & Deutsche Postbank AG \\
\hline & LBB Holding AG-Landesbank Berlin Holding AG \\
\hline \multirow[t]{5}{*}{ France } & BNP Paribas \\
\hline & Credit Agricole S.A. \\
\hline & Natixis \\
\hline & Societe Generale \\
\hline & Credit Industrial et commercial \\
\hline \multicolumn{2}{|c|}{ (2) Banks from developing countries } \\
\hline Country & Bank \\
\hline \multirow[t]{9}{*}{ India } & Allahabad Bank \\
\hline & Andhra Bank \\
\hline & Bank of Baroda \\
\hline & Bank of India \\
\hline & Canara Bank \\
\hline & Central Bank of India \\
\hline & Corporation Bank Ltd. \\
\hline & HDFC Bank Ltd \\
\hline & ICICI Bank Limited \\
\hline
\end{tabular}




\begin{tabular}{|l|l|}
\hline & Indian Bank \\
\hline & Indian Overseas Bank \\
\hline & State Bank of India \\
\hline & Syndicate Bank \\
\hline China & Agricultural Bank of China Limited \\
\hline & Bank of Beijing Co Ltd \\
\hline & Bank of China Limited \\
\hline & Bank of Communications Co. Ltd \\
\hline & China CITIC Bank Corporation Limited \\
\hline & China Construction Bank Corporation \\
\hline & China Merchants Bank Co Ltd \\
\hline & China Minsheng Banking Corporation (private bank) \\
\hline & Industrial \& Commercial Bank of China (The) - ICBC \\
\hline & Industrial Bank Co Ltd \\
\hline & Shanghai Pudong Development Bank \\
\hline & Huaxia Bank Co. Ltd. \\
\hline & Bank of Nanjing Co. Ltd. \\
\hline & China Everbright Bank Co. Ltd. \\
\hline & Ping An Bank Co. Ltd. (private bank) \\
\hline & Bank of Ningbo Co. Ltd. \\
\hline & \\
\hline &
\end{tabular}


Appendix B.

Table 14 "Common law" vs "civil law" countries

\begin{tabular}{|c|c|}
\hline Common Law & $\begin{array}{l}\text { There are } 27 \text { banks in our sample belong to this category and these banks are from } \\
\circ \text { Ireland } \\
\circ \text { USA } \\
\circ \text { Australia } \\
\circ \text { UK } \\
\circ \text { Canada }\end{array}$ \\
\hline Civil Law & $\begin{array}{l}\text { There are } 36 \text { banks in our sample belong to this category and these banks are from } \\
\circ \text { Belgium } \\
\circ \text { Spain } \\
\circ \text { Portugal } \\
\circ \text { Netherlands } \\
\circ \text { Switzerland } \\
\circ \text { Denmark } \\
\circ \text { Norway } \\
\circ \text { Austria } \\
\circ \text { Sweden } \\
\circ \text { Finland } \\
\circ \text { Italy } \\
\circ \text { Germany } \\
\circ \text { France }\end{array}$ \\
\hline
\end{tabular}

